\title{
"Visualidade" educacional na Guiné-Bissau à luz da teoria de banda desenhada, ou seja, uma revisão trans/pós-colonial das ideias didáticas/pedagógicas no âmbito da lusofonia ${ }^{1}$
}

\author{
Educational "visuality" in Guinea-Bissau in the light \\ of comic book theory. A trans/postcolonial review \\ of didactic/pedagogical ideas in the scope of lusophony \\ (written in disagreement with the new spelling agreement)
}

\author{
Jakub Jankowski \\ Universidade de Varsóvia \\ jakub.s.jankowski@uw.edu.pl \\ Piotr Stańczyk \\ Universidade de Gdańsk \\ piotr.stanczyk@ug.edu.pl
}

\begin{abstract}
The main purpose of the article is to present analysis of comic book No Pintcha which - as we state - is the exceptional example of visual representation of theory of education from period of early independence of former portuguese colonies in Africa. Nô Pintcha was published in 1978 during the summit of ministers of education and educators from Angola, Cape Verde, Guinea Bissau, Mozambique and São Tomé. Authors of Nô Pintcha considered comic book as a apendix to the basic literacy campaign in Guinea Bissau. Theory of education which was used during literacy campaign had origins of emancipatory popular education of Paulo Freire. Thus the analysis presented in this paper lies parallely in looking for the Nô Pintcha in perspective of comic book theory as well in looking for traces Freire's theory.
\end{abstract}

Keywords: comic book, openess, postcolonialism, popular education, basic literacy campaign, Guinea Bissau

\footnotetext{
${ }^{1}$ Escrito em desacordo com o novo acordo ortográfico.
} 
Em homenagem ao "PRIMEIRO ENCONTRO DE EDUCADORES. ANGOLA. CABO VERDE. GUINE BISSAU. MOCAMBIQUE. S. TOME E PRINCIPE. FRETLIN" (grafia original), realizado em Bissau nos dias 15-21 de Fevereiro de 1978, foi publicada banda desenhada (BD) Nô Pintcha (suplemento especial: reconstrução-educação) que procurava mostrar os problemas que os países posteriormente às independências chamados de PALOP (oficialmente desde 1992), encontravam na tarefa de reconstrução nacional. Uma das áreas mais importantes na dita reconstrução era a educação que num esforço de alfabetização ganhou moldes Freiristas consideráveis na Guiné-Bissau (GB) e em São Tomé e Príncipe (STP). A influência do pensamento de Paulo Freire nos países supra-referidos pode ser vista como comparável aos raciocínios de grandes intelectuais como Foucault ou Bourdieu.

No presente artigo pretendemos primeiro analisar a influência e contornos educativos propostos por Freire para a alfabetização da sociedade guineense e sãotomense, e depois rever e reler um artefacto polissemiótico (BD) da GB à luz da teoria contemporânea de $\mathrm{BD}$, bem como buscar actualizadas referências aos velhos problemas sociais. Interessar-nos-á ver em Freire como o método dele (escolhendo o povo oprimido como o agente de mudança e tendo o apoio ideológico do partido PAIGC) terá contribuído para a emancipação das sociedades póscoloniais (primeiro para a emancipação material que possibilita a posterior emancipação intelectual). Este método ajudou a combater alguns dos mitos que a educação da metrópole tentara impor durante o período colonial. Tendo em conta esses pressupostos, propomos reler um dos textos (sensu lato) auxiliares ${ }^{2}$ ao processo educativo de Freire à luz do pensamento teórico vigente na abordagem crítica na área dos estudos de BD. Essas novas leituras das ideias clássicas Freiristas, apresentadas nos meios visuais, visam rejeitar a ideia de compreender BD como um meio que empobrece as capacidades cognitivas do leitor e que ameaça a sua sanidade psicológica. Contemporaneamente na teoria de BD rejeita-se cabalmente esse tipo de ideias uma vez expostas pelo psicólogo norte-americano F. Wertham, apresentadas no livro Seduction of the Innocent (1954) ${ }^{3}$. A pedagogia cultural, por sua vez, baseada em Freire e Ranciere, possibilita perceber que o contacto com vários conteúdos proporciona uma valiosa experiência educativa, sobretudo quando os conteúdos culturais são produzidos pelos próprios oprimidos. A BD por nós escolhida consciencializa e visualiza os desafios da educação num país como GB, e entendemos que tomar consciência do problema é o primeiro passo para o resolver.

\footnotetext{
${ }^{2}$ Auxiliar, porque a BD por nós escolhida não serve como manual de alfabetização, mas é antes um resumo das ideias Freiristas, várias vezes humorístico, uma apresentação de história e da realidade educacional da GB. O público-alvo principal deste conteúdo não são analfabetas, sejam eles jovens, sejam adultos, mas pessoas que já sabem ler, e que sabem decifrar a mensagem visual sob a forma de uma BD.

${ }^{3}$ Um excerto deste livro (o original de 1954 e a segunda edição de 1999, embora acessíveis, atingem preços elevadíssimos tornando-se praticamente inacessíveis) pode ser lido no A Comics Studies Reader, ed. por J. Heer e K. Worcester, Univeristy Press of Mississippi, Jackson 2009, p. 53-57.
} 
Optamos por mostrar o carácter auxiliar de BD no ensino (tal como p.ex. no ensino de História, como nos explica B. Janicki em Dydaktyczny potencjat komiksu historycznego, 2016; ou ainda como os autores do livro orientado por Frey/Fisher alegam em Teaching Visual Literacy, indicando BD como um dos meios que servem para desenvolver as capacidades de compreensão e de raciocinar - a BD é varias vezes erroneamente vista como fácil na recepção porque é visualmente atraente, e não se dispensa o devido esforço no processo de descodificação da mensagem nela contida), e compreendemos a BD como uma "obra aberta" que pode realizar hoje em dia várias funções devido à abertura da sua estrutura e do seu conteúdo intertextual (como nos explica, entre outros teóricos de BD, M. Ahmed em Openess of Comics. Generating Meaning within Flexible Structures, 2016 baseando-se na ideia original de "opera aperta" de Umberto Eco).

Tendo em conta a marginalização de BD tanto como meio artístico (sobre esta perspectiva fala, entre, outros, B. Beaty em Komiks kontra sztuka, [2012] 2013, ou J. Szyłak na entrevista com S. Frąckiewicz em Wyjście z getta, 2012), como um auxílio educacional, será interessante juntar esta perspectiva com a perspectiva dos povos uma vez oprimidos, também marginalizados, e ver como a tensão entre o texto como uma experiência e texto como um objecto ("text as experience vs text as object" em Hatfield Alternative Comics. An emerging literature, 2005) influencia a leitura contemporânea, quiça pós-, quiçá trans-colonial, dos artefactos educativos e contextos ideológicos dos anos 1970 na GB.

$\mathrm{O}$ objecto do nosso estudo, uma história em BD, Nô Pintcha (crioulo: em frente!), compreende igualmente o nome da editora, isto é, trata-se do maior jornal da $\mathrm{GB}$ ao serviço do PAIGC, mas dá também o título à $\mathrm{BD}$ em questão. Esta $\mathrm{BD}$, o que é crucial para a nossa interpretação, é publicada como material auxiliar ao manual que exerce a função do abecedário para adultos e que foi usado nos anos da independência recém-ganha na alfabetização inicial dos adultos. $O$ próprio manual nasce também como um dos artefactos da cultura popular.

Através do conteúdo desta BD podemos perceber o âmago das negligências propositadas pelo regime racial-fascista do Portugal Colonial na área de educação, a recordação viva da guerra, bem como esperanças e entusiasmo vivido trás a proclamação da independência (unilateral em 1973, reconhecida por Portugal em 1974 Rosas 2018, p. 181-183), mas também uma comparação da situação na altura com métodos e conteúdos de aprendizagem ancestral/tradicional (anterior). Mais importante ainda parece neste contexto o facto de os Guneenses terem recorrido ao pensamento e habilidades de Paulo Freire, clássico da literatura científica, que ficou envolvido pessoalmente na organização do sistema de educação na GB independente.

Paulo Freire (1921-1997), educador brasileiro e filósofo de educação, é sem dúvida nenhuma, um dos autores da língua portuguesa mais lidos. A força da sua influência na cultura mundial manifesta-se, entre outros, através da posição indicada pelo "índice h" de Hirsch e através do carácter aplicativo da sua teoria. Que prova 
disso seja o facto de que não há outro autor do séc. XX na área da teoria de educação tantas vezes referenciado que Freire. O "índice h" de Hirsh no caso de Freire é de 149, e a obra mais popular dele, Pedagogia do Oprimido na versão inglesa, foi referida em mais do que 67000 textos científicos (Publish or Perish). Os índices-marcadores, claro está, não são suficientes para alegar o classicismo de um clássico. Acrescentemos então que o método que ele criou, foi usado em todo o mundo, às vezes no contexto e realidade de todo o país em questão (Gadotti, 1996). O método de Freire usa-se ainda hoje me dia, sobretudo como uma combinação de acções educacionais com actividades sociais (Assumpção, 2009; Brandão, Assumpção, 2009; Mafra, Romão, Scocuglia \& Gadotti, 2009). Por exemplo, o programa brasileiro de política social Bolsa Família está enraizado na filosofia de Paulo Freire, também um dos membros fundadores do Partido dos Trabalhadores. Eis o partido que implantou este programa social no Brasil (Dowbor, 2016, p. 21-38; Eiró, 2016, p. 39-55). A filosofia de educação e a actividade educacional de Paulo Freire impulsionaram também o desenvolvimento dos estudos mundiais de letras e do pensamento social. A melhor prova disso é a importância do trabalho deste filósofo e educador brasileiro para os pesquisadores americanos na área do ensino, que na viragem dos anos 1970. e 1980. criaram o paradigma da pedagogia crítica (Giroux, 2001; Hooks, 1993; McLaren, 2000) - o paradigma que hoje em dia alimenta estratégias interpretativas, de pesquisa e de intervenção no que diz respeito ao mundo escolar e mundo social.

Vale a pena sublinhar ainda que um fenómeno muito interessante e promissor dos últimos anos no âmbito da teoria de educação é - inspirada tanto na filosofia de Freire, como na teoria do «professor ignorante» de Jaques Rancière (1991), na teoria do «actor-rede» de Bruno Latour (2005) e na teoria de governamentalização de Michel Foucault (2009) - a pedagogia do objecto («thing-centered pedagogy»), onde a análise e prática educacional concentram-se não somente nas relações interpessoais, mas sobretudo nas interacções mútuas dos sujeitos dos processos educacionais com os objectos materiais, ou com os objectos de valor simbólico (Biesta, 2010; Vliege, 2016; Hodgson, Vliege, Zamojski, 2017). Na reinterpretação de Paulo Freire à luz da pedagogia do objecto existe ainda um traço importante polaco. Revela-se que no período de escrever do seu opus magnum, Pedagogia do Oprimido, Freire está fortemente influenciado pela teoria da pedagogia materialista do filósofo polaco de educação, Bogdan Suchodolski (Mafra, 2010; Stańczyk, 2018). Ao nosso ver a BD Nô Pintcha visualiza o âmago da teoria e do método de Freire do período da fascinação dele pela pedagogia materialista que foi por ele aplicada nas campanhas de alfabetização na África "emancipante" do jugo colonial.

O importante em Freire é o facto de que, se existir qualquer erro interpretativo dos pressupostos dele perante a forma de como se deve educar, ou seja, se existir qualquer discrepância entre a teoria e os efeitos práticos, este erro nasce de quem interpreta, não de quem propõe. O método de Freire não é de maneira nenhuma infalível. Este facto é de extrema importância no que diz respeito à obra que será 
analisada no nosso artigo, Nô Pintcha, e o problema identificado na Guiné-Bissau quanto à campanha de alfabetização baseada no método de Freire consiste no facto de que este método não deu resultados esperados, o que provam tanto as fontes de observadores de fora, como Linda M. Harasim (1983), como a documentação oficial do Governo, como por exemplo o relatório de Paulo Pereira (1989). Catorze anos de alfabetização na GB, segundo Pereira, mostram que o sistema educacional continua a não responder às necessidades da maioria da sociedade e permanece extremamente selectivo o que tolha o desenvolvimento (Pereira, 1989, p. 2). Pereira descreve os resultados da primeira fase da campanha de alfabetização à Freire (1975-1979) como "quase nulos" (Pereira, 1989, p. 2) devido ao facto de que esta abrangeu apenas 26000 dos analfabetos adultos, ou seja, apenas $7,5 \%$ da população na faixa etária produtiva com o analfabetismo geral de $98 \%$ (Pereira, 1989, p. 2). No regime de comparação vejamos que em STP o mesmo tipo da campanha de alfabetização durante os quatro primeiros anos abrangeu $72 \%$ dos analfabetos adultos e o nível de analfabetismo de $98 \%$ entre adultos caiu para $45 \%$ (Gerhardt, 1996, p. 165). Os resultados tão diferentes para uma campanha baseada nos mesmos pressupostos surgem devido à situação linguística diferente da GB e de STP. Em STP usa-se a língua portuguesa, a língua da alfabetização, como a língua veicular o que o faz dela uma língua tanto oficial, como dominante. Na GB a situação linguística é muito mais complexa, pois a língua portuguesa indicada como a língua de alfabetização, tendo o estatuto de uma língua oficial, é usada apenas por $11 \%$ da população (conforme os dados da altura). Para comparar, o crioulo atinge o nível de $45 \%$, Balanta de 24,5\%, Fula de 20,3\%, Mandinga de $10,1 \%$ e Manjaco de $8,1 \%$, o que ainda não abrange grupos linguísticos mais pequenos (Pereira, 1989, p. 2-4). Freire e Freiristas culpam a situação linguística pelo fracasso, e não o próprio método (Torres, 1993, p. 135; Torres, 1996, p. 141; Freire, Faundez, 1998, p. 62-63). Ainda no ano 1980 na GB começam programas-pilotos para recorrer a Crioulo, Balanta, Fula, Mandinga, Manjaco na campanha de alfabetização à Freire (Pereira, 1989, p. 4-6; „No Pinca”, 1989), mas hoje em dia ao trabalhar com os analfabetas adultos recorre-se ao método cubano Sim, eu posso (é um método mais conservador, ou seja, caracteriza-se pelo carácter colonizador).

Neste cenário linguístico o português usado na BD em questão pode suscitar algumas dúvidas. A escolha estratégica da língua portuguesa no processo educativo tem a ver com a procura dos elementos que podiam construir uma nova identidade nacional e mostra afinidades com o pensamento compartilhado também fora das fronteiras do mundo africano da língua portuguesa. Quando o nigeriano Chinua Achebe no ensaio "Política e políticos da língua na literatura africana" fala sobre a situação linguística na Nigéria, ele afirma no espírito pan-africano que atitudes linguísticas extremas que forçam o uso ora da língua do ex-colonizador, ora da língua da etnia, não adiantam nada e na verdade é mais proveitoso aceitar as duas (Achebe, 2012 [1989], p. 109). Para ele o problema de multilinguismo não é o efeito 
do imperialismo, mas do pluralismo das sociedades africanas (Achebe, 2012 [1989], p. 119). Embora esta primeira constatação pareça um tanto simplificada, o interessante é que Achebe indica ainda a GB entre os países que menos hesitaram em aceitar a língua do ex-colonizador. Talvez sim, mas sabemos que o resultado da generalização de português na GB não equivale a sucesso. Segundo as estimativas (de 2007) que em 2013 apresentou Hlibowicka-Węglarz, apenas 11,1\% dos guineenses falavam português (Hlibowicka-Węglarz, 2013, p. 177). O Ethnologue (https://www. ethnologue.com/country/GW) indica que a taxa de alfabetismo é de $55 \%$ e aponta português L1 para 5280 guineenses (dados de 2016) e como L2 para 391 mil (dados de 2015). Em total são 396280 mil falantes de português (22\%). Podemos então ver que o crescimento do uso de português é bastante lento, mas existe. O mais importante hoje em dia é ainda a consciência, que paira entre os guineenses, da importância de falar português. Um dos entrevistados por Magdalena Brzezińska no projecto de doutoramento dela realizado nos contornos antropológicos da observação participante durante duas estadias na GB, publicado depois em livro (Brzezińska, 2017), diz que o crioulo só serve para se comunicar na GB, mas português é mais útil do que crioulo porque se pode usá-lo em CV, STP, Angola e Portugal. Então, por um lado, segundo o entrevistado é uma mais-valia na perspectiva de emigrar, mas por outro, ele não a considera natural (Brzezińska, 2014, p. 390).

Paulo Freire chega a Bissau em 1975. As actividades organizativas dos educadores podem ser acompanhadas no jornal „Nô Pintcha” que desde 29 de Janeiro de 1976 tem a secção semanal „ANO I DE ORGANIZAÇÃO: PÁGINA DO COMISSARIADO DO ESTADO DA EDUCAÇÃO E CULTURA”. A importância dada às questões de educação é, por assim dizer, endémica, mas na GB, um país recém-independente, o sistema educacional tem de ser edificado desde as bases. A discussão é calorosa e as decisões tomadas terão dado os resultados na perspectiva mais longa.

A própria alfabetização é metaforizada como uma luta quando, por exemplo, se refere aos educados nas palavras de Cabral: "Os bons alunos são como os bons combatentes: os melhores militantes do nosso grande PAIGC" (NP, 12 de Fevereiro 1976). E o conceito de alfabetização segue definido assim:

Alfabetizar e ser alfabetizando significa participar consciente e politicamente na marcha vitoriosa da total libertação de cada um e de todos os filhos da nossa terra, agora no caminho de Reconstrução Nacional.

Especialmente para ti, jovem, será indispensável na realização deste objectivo.

Terás de assumir a responsabilidade que te cabe; terás de responder ao desafio da construção de um futuro aberto para a paz e o progresso de todo o nosso povo.

Uma por uma, iremos ganhando as batalhas. A batalha contra o analfabetismo, essa também a ganharemos, com a tua ajuda desinteressada (NP, 15 de Janeiro 1976).

Uma análise dos materiais dos anos 1976-1978 possibilita perceber que existem dois eixos-chave de discussão/opção pedagógica. A autoridade simbólica, o árbitro 
que tem voz decisiva nela, é Amílcar Cabral. Primeiro ponto de discussão é o método de alfabetização e abrange a possibilidade de escolher o método de Freire ou o método cubano. Esta escolha parece continuar em aberto até ao dia de hoje quanto à alfabetização dos adultos. Moacir Gadotti, colaborador de Freire, embora esteja bem impressionado pela efectividade e rapidez do método cubano (os autores desta concepção alegam que são capazes de alfabetizar no período de 35 dias), chama a atenção ao carácter sujetivizante e instrumentalizante deste, bem como à incompatibilidade do programa com o contexto local sóciocultural (Gadotti, 2009, p. 20). As razões mais importantes em Cabral, que apontam para as afinidades com o pensamento de Freire, compreendem (sendo a base da educação popular) o reconhecimento do povo e da cultura popular, o carácter anticolonial do ensino (sendo o conceito da descolonização das mentes aqui crucial), o carácter radicalmente democrático nos processos de aprendizagem e a ligação entre o processo de aprendizagem com os processos de transformação do mundo, ou seja, com o trabalho (Romão, Gadotti, 2012).

Segundo ponto de discussão tem a ver com a escolha da língua portuguesa como a língua de alfabetização inicial ou com a decisão de recorrer neste processo às línguas usadas pelas etnias. Aqui Cabral outra vez torna-se num árbitro. A 15 de Abril de 1976 é publicado o artigo „A LÍNGUA PORTUGUESA É UMA DAS MELHORES COISAS QUE OS TUGAS NOS DEIXARAM. PORTUGUÊS OU CRIOULO?", no qual se resolve esta questão tal como o profeta e herói nacional, referido como "Professor No. 1", quer. A escolha de português é justificada assim:

Muitos camaradas querem ir para frente com o crioulo. Nós vamos fazer isso, mas depois de estudarmos bem. Agora a nossa língua para escrever é o português. Não somos mais filhos da nossa terra só porque falamos o crioulo. Mais filho da nossa terra é aquele que cumpre as leis do Partido, as ordens do Partido, para servir bem o nosso povo. Ninguém deve ter complexos porque não sabe balanta, mandinga, papel ou fula ou mancanha. Se souber, melhor, mas se não sabe, tem que fazer com que os outros entendem, mesmo que seja com gestos. (...) Temos que ter um sentido real da nossa cultura. $\mathrm{O}$ português (língua) é uma das melhores coisas que os tugas nos deixaram, porque a língua não é senão da prova de um instrumento para os homens se relacionarem uns com outros. (...) A língua é um instrumento que o homem criou através do trabalho, da luta para comunicar com os outros homens. (...) Mas o mundo avançou muito, nós não avançamos muito, tanto como o mundo, e a nossa língua ficou a nível daquele mundo a que chegamos, que vivemos (...). Por exemplo, nós dizemos assim: a Lua é um satélite natural da Terra. Satélite natural. Digam isso em balanta, digam em mancanha. (...) (NP, 15 de Abril 1976).

Por fim na alfabetização usou-se o método de Freire e a língua portuguesa. Obviamente são apenas duas características de uma campanha que se inscreve no processo da reconstrução nacional e da descolonização das mentes. Em Fevereiro de 1978 tem lugar „Encontro dos Ministros da Educação das ex-colónias” onde se discute as questões dos alvos e da organização da alfabetização nos territórios 
coloniais portugueses. Este encontro segue relacionado nas páginas do jornal „Nô Pintcha", e como o alvo aponta-se "a construção nos nossos países independentes de sociedades novas, verdadeiramente democráticas e libertas para sempre de todas as formas de exploração" (NP, 16 de Fevereiro 1978). A série de artigos vem acompanhada por uma BD que apresenta o método de Freire. A BD que a seguir analisaremos compreende um desafio popularizador que visa aproximar um público maior da complexidade dos assuntos ligados à educação, e sobretudo criticar a educação conservadora que colonizou as mentes, contrapondo-a à educação popular - a alternativa.

\section{FILOSOFIA DE FREIRE E A SUA IMAGEM NA BD NÔ PINTCHA}

Para chamar a atenção à BD vista como uma obra aberta recorreremos ao pensamento de M. Ahmed que adaptou o conceito original de Eco para mostrar como a BD consegue gerar openess (abertura). Reconhecer esta capacidade de abertura da BD possibilita leituras diacrónicas e sincrónicas separadamente ou paralelamente. Nós fazemos as duas e de ambas as formas: quanto ao conteúdo procuramos na BD Nô Pintcha as características da filosofia de educação de Freire e ao mesmo tempo tentamos trazer uma visão social actualizada dos fenómenos que nela aparecem, e quanto à forma tentamos medir Nô Pintcha pelos conceitos teóricos contemporâneos no âmbito de $\mathrm{BD}$. O importante é que as referências sociais actualizadas por nós usadas de vez em quando aparecem na ordem transfronteiriça, ou seja, algum fenómeno identificado em Nô Pintcha hoje em dia manifesta-se com mais força no outro PALOP, não necessariamente na GB. Achamos esta atitude metodológica viável por pelo menos duas razões: uma é que Nô Pintcha pode referir-se directamente à GB, mas o encontro dos educadores que acompanhou, foi de todos os PALOP, ou seja, a BD Nô Pintcha pode exemplificar os problemas do ensino recorrendo à $\mathrm{GB}$, mas na verdade transmite uma mensagem mais universal palopeana; a segunda é que a visão do processo da "colonização das mentes" que partilham cidadãos palopeanos hoje em dia, tem as raízes no sistema unificado de gestão de todo o Ultramar.

Ahmed, que é o nosso ponto de referência estrutural quanto à BD vista como género, relembra que segundo Eco openess compreende, a quem experiencia uma obra, a possibilidade de levar a cabo várias interpretações contidas (intrínsecas) tanto na narrativa coesa, como na estrutura estética (Ahmed, 2016, p. 3). De um dado processo de leitura aberto nasce o significado que pode surpreender a quem achar a BD um meio fácil e incapaz de transmitir conceitos complexos. A BD pode gerar openess de duas formas: referenciando o ambiente exterior (sendo intertextual) e recorrendo às ligações internas na estrutura (Ahmed, 2016, p. 4). Segundo Eco podem até existir tal chamadas obras em movimento, ou seja, o tipo de obras 
construídas pelas unidades não planeadas ou fisicamente incompletas (Eco apud Ahmed, 2016, p. 5). Por isso estamos de acordo com Ahmed quando ele sugere que a própria estrutura da $\mathrm{BD}$ é aberta porque incompleta em si, p.ex. podem nela existir intervalos físicos entre imagens (e mesmo que não existam fisicamente, que não os vejamos, aparecem na nossa mente quando passamos de uma imagem para outra; a nossa tarefa, como leitores, é preencher esses intervalos até conseguirmos recriar todas as ligações e a sequência completa), chamados por McCloud gutter (sarjeta), que nós preenchemos recorrendo a closure (conclusão) (McCloud, 1995, p. 60-93) ${ }^{4}$. Esta conclusão é obviamente aberta ao que nós imaginamos passando de um quadro para outro, ou seja, somos nós quem preenche a sarjeta. Ao mesmo tempo a ambiguidade dos signos que vemos não pode ser separada desta sua organização estética (Ahmed, 2016, p. 5). Aliás, tanto Eco como Ahmed alegam que openess é diferente de uma liberdade total de interpretação e que uma obra oferece interpretações únicas, mas limitadas em número. A ambiguidade, e daí openess, nascem da força de sugestão e de grau de inconvencionalidade (Eco apud Ahmed, 2016, p. 7) de uma obra. Como veremos em Nô Pintcha, a força de sugestão reside na metaforização imagética dos fenómenos descritos ("Metaphors, for instance, by widening the range of meaning encompassed by a particular sign, also subvert conventions" Eco apud Ahmed, 2016, p. 13), e a inconvencionalidade manifesta-se sobretudo nas relações indirectas imagem-palavra (característica sublinhada em openess por Ahmed) que criam efeitos de tensão/humorísticos, e que se interligam com a metaforização. Por isso, entendemos que openess gerado na BD em questão é bastante complexo. O símbolo que aparece no desenho metaforizado pode-se ligar com a rede de outros textos, sendo no nosso caso, p.ex., os textos teóricos de Freire, mas não só. Para além desta ordem da leitura sincrónica $\mathrm{BD} \leftrightarrow$ Freire, tentaremos também recorrer à leitura diacrónica do conteúdo, evocando a situação actual que se liga com os fenómenos observados nos anos 1970. Então, podemos ler Nô Pintcha através de Freire, que é uma intertextualidade óbvia, mas pretendemos ainda mais: a leitura diacrónica tanto quanto ao conteúdo, como quanto à forma. Pois, lembremo-nos que Nô Pintcha é uma BD, então, estruturalmente realiza a priori o conceito de openess. E quanto ao conteúdo detalhado imagético e verbal? Vejamos.

Quanto ao aspecto linguístico, ao qual chamámos a atenção na primeira parte deste artigo, vale a pena ainda citar Augusta Henriques, uma guineense entrevistada por Joana Gorjão Henriques na série de reportagens Racismo em português, que critica o uso da língua e realidade portuguesas no ensino na GB, afirmando com indignação:

\footnotetext{
${ }^{4}$ A questão de como foram traduzidos para português do Brasil os termos-chave de McCloud merece uma reflexão a parte e de certeza um dia fá-la-emos, mas por enquanto remetemos os leitores interessados à revista Zeszyty Komiksowe \#23 (2017) (Jankowski, 2017, p. 62-78; Traczyk, 2017, p. 80-85), e Zeszyty Komiksowe \#25 (2018) (Jankowski, 2018, p. 90-101) onde encontrarão artigos sobre o desafio problematizado da tradução de McCloud para polaco.
} 
A história do ensino marcou incrivelmente o que é a Guiné hoje. Foi feita sempre numa língua estrangeira [o português]; foi feita sempre com um referencial que o guineense não conhece, foi feita sempre com um mundo que não é seu, aonde eu tinha de recorrer à memória, perceber pela astúcia o que é que o outro quer que eu lhe responda, não o que é certo e errado, mas o que ele espera - e até hoje o guineense tem isto (Gorjão Henriques, 2016, p. 79).

Augusta Henriques, hoje em dia, mostra uma atitude diferente frente à língua do colonizador do que nos moldes iniciais justificava Cabral: chama português de língua estrangeira e faz referência ao modo de ensino transportado da colónia, totalmente desfasado da realidade guineense. Ela, historicamente, não vê nenhuma utilidade da língua portuguesa. A este tipo de ensino que ela descreve, "portucéntrico", revoltavam-se Freire e Cabral, e este tipo do ensino que vemos criticado em $N o ̂$ Pintcha. Mas vejamos bem: critica-se no pensamento dos dois o sistema imposto, não a língua do impostor.

$\mathrm{Na} \mathrm{BD}$ em questão, escrita em português, vemos várias metaforizações da situação educacional realizada nos moldes do ensino colonizador. Por exemplo a escola está literalmente nas nuvens, inatingível para o povo que trabalha (Fig. 1), é um lugar por um lado circunscrito e físico, diferente do espaço associado pelos guineenses com a aprendizagem tradicional, por outro totalmente fantasmagórico para eles. A expressão "estar nas nuvens" aponta para imobilidade da instituição abstracta (fixo "estar") e inatingível (abstracto "nas nuvens"), e confina o povo a uma posição curvada (jugo do trabalho, quiçá ainda referido ao trabalho obrigatório do sistema colonial) a andar na terra (povo móvel), não nas nuvens, com os pés bem assentes na terra firme (aprendendo coisas pragmáticas).

$\mathrm{O}$ ensino dessas escolas nas nuvens era visto como opressor o que em $N \hat{o}$ Pintcha é visualizado, entre outros, pelos livros que criam paredes como se se tratasse de uma prisão (Fig. 2). Estas duas metaforizações são simbólicas e no tradicional método criativo de banda desenhada, "przerysowanie" [redesenhar + exagerar] combinado com a técnica de cartoon [satirizar + abstrair], abrem a margem para interpretações. Obviamente esta interpretação imagética vem reforçada pelas palavras que não deixam ao leitor abrir a interpretação demasiado, ou seja, não possibilitam a interpretação totalmente livre. A possível abertura (openess) é limitada a pelo menos duas opções interpretativas diacrónicas: “antes era assim e agora é (...)?”.

Antes de chegarmos a essas metaforizações da situação colonial, quase logo no início da narrativa vemos dois rapazes que estão a voltar da escola e a falar sobre o que acabam de aprender. Revela-se que a nova escola, recorrendo às matérias como matemática, ensina contar nos exemplos muito práticos: cultivo (Fig. 3) e combate a paludismo que continua a ser um dos desafios da sociedade actual (Fig. 4).

Tendo em conta a realidade do ensino na GB depois da independência, é importante aperceber-se que no mundo diegético imergimo-nos logo no início em toda esta história no modelo tradicional do ensino: a escola da qual saem duas crianças 
não é um prédio tipicamente associado à escola no sistema europeu (o tipo da escola que vemos nas nuvens), é antes um espaço aberto, e a forma como os dois conhecem a história do ensino na GB é, no nível diegético oral, falada por um velho-sábio debaixo de uma árvore. Os livros que formavam a prisão educativa colonial ficam substituídos pela oralidade. É isso que nós vemos melhor na conclusão aberta desta história: as crianças levantam-se e no plano geral vemos "os professores" deles que acabam de proferir a lição debaixo de um embondeiro (Fig. 5). A receita pronta para a nova escola guineense só irá nascer, mas de certeza é que será o consenso entre todos, pois uma das crianças diz no fim: "Espera, vou chamar os outros". Os protagonistas de Nô Pintcha, a imagem dos guineenses nos anos 1970, ficam como se pendurados e assim fica a obra que estamos a ler - aberta. A situação real de incerteza sobre os moldes do sistema educativo gera openess da conclusão diegética em aberto. Mas é pertinente chamar a atenção ao facto de que a criança quer trazer os outros para debaixo da árvore, como se estivesse a sugerir que neste espaço, e com o professor que acaba de ouvir, se devia aprender: não numa escola nas nuvens, mas debaixo das nuvens.

O que é crucial na perspectiva temporal transversal, ou seja, na nossa leitura diacrónica e sincrónica, é o facto de que segundo Ahmed pode existir na $\mathrm{BD}$ um tipo de openess que faz ligação com a realidade, ou seja, que fala sobre algo familiar ao leitor:

The effects of the kind of verisimilitude or abstraction, involved in both words and pictures, can also contribute towards the openess of comics, notably through creating ambiguity or through references to reality, which become self-reflexive when the medium's role in filtering reality is made evident. The degree of verisimilitude can be gauged on an axis posting abstraction on one end and realism on the other. Verisimiltude or the "neutralisation erasing the reality/fiction gaps reinforced when the work begins by adopting the perspective of the everyday". It serves to place the reader in the protagonist's shoes because of which "we are not in the presence of a story which is beginning but a life which is continuing (Ahmed, 2016, p. 17).

A filtragem da realidade colonial faz-se através das metáforas e a realidade póscolonial é-nos trazida pela verosimilhança da situação diegética que ilustra o ensino no cotidiano dos guineenses dos anos 1970. Tanto os leitores sincrónicos de Nô Pintcha, como leitores conscientes diacrónicos (nós, hoje em dia, que conhecemos a filosofia de Freire), podem ser considerados como "postos nos sapatos dos protagonistas". É vida e realidade que continuam para além das páginas de BD em 1978, e desafios que até hoje só parcialmente é que foram resolvidos, ou seja, a vida realmente continua. Entendemos que uma BD como Nô Pintcha está imersa na realidade da $\mathrm{GB}$ e dos oprimidos que procuram encontrar-se na realidade nova do país. Como leitores, no nível meta, acompanhamos uma BD, um meio narrativo tradicionalmente não guineense. É interessante reinterpretar neste âmbito uma tensão 
superior identificada por Hatfield (várias tensões entre unidades interactivas de BD por ele enumeradas podem levar à criação de significados) como "text as experience vs. text as object" (Hatfield, 2005, p. 58-65), combinada com a tipificação histórica da BD africana por J. Lent (2011, p. 255-280).

Hatfield fala sobre uma materialidade peculiar de uma $\mathrm{BD}$, ou seja, de como o texto (conteúdo) pode ser reforçado pelos aspectos como edição, tamanho, encadernação etc., ou seja, de como pela estética aceite podem ser gerados ou reforçados os significados. Vejamos que esta categoria pode ser estendida e compreendida no nosso caso com se a tensão criativa nascesse entre o conteúdo (didáctico, educacional) e o próprio objecto (BD) que o realiza, que toca uma temática para este meio inusitada, sobretudo nas duas primeiras etapas da história da implantação da BD em África que Lent descreve como (1) a transferência da BD branca da metrópole e (2) criação da BD na colónia pelos brancos. Só na terceira etapa Lent identifica o surgimento dos temas locais (Lent, 2011, p. 258), quiçá iguais a esses que aparecem em Nô Pintcha. Esta tensão de Hatfield reinterpretada, entre o texto como experiência e o texto como objecto, ao nosso ver, realiza mais uma das vertentes possíveis de openess.

Mais uma perspectiva sobre o ensino abre-se quando os autores da $\mathrm{BD}$ em questão falam sobre a África pré-colonial onde na consequência de não haver escolas, não havia doutores e diplomas. A imagem que o ilustra (Fig. 6) é bem curiosa: um homem negro com vestido tradicional estereotipizado (saia de palha?) que veste ainda boné universitário e na mão levantada tem canudo. Esta imagem pode querer exagerar o peso de aprendizagem no modelo desconhecido na África subsariana (o canudo levantado parece um peso do ginásio). A aprendizagem que existia tinha moldes práticos o que explica às crianças o velho-sábio logo a seguir. Talvez a postura do homem gorducho nesta imagem queira ilustrar o ridículo possível de tentar educar os indígenas nos moldes lhes desconhecidos e inúteis? Talvez se queira evidenciar que sem doutores formados nem se podia ousar a pensar sobre educar o povo? Esta imagem possibilita essas leituras e talvez mais ainda, ou seja, através da simbologia mista dos elementos africanos estereotipizados e universitários nasce aqui um símbolo de ricas conotações. A sugestividade que conduz a este caso de openess manifesta-se pela ordem textual-imagética.

O interessante é que mais tarde na narrativa aparece uma imagem de toda a página que nos mostra um africano já formado que conduz uma máquina aplanadora que em vez do mecanismo aplanador usa "diploma" (Fig. 7). Volta o motivo de peso de educação e torna-se óbvio que todos têm consciência da utilidade de aprendizagem proposta nos moldes colonialistas, mas aqui ela é mostrada como uma consequência da educação selectiva colonialista que levava a criar classes na sociedade colonizada. Ou seja, criava homens privilegiados que passavam a oprimir o povo menos bem educado. Este caso é bem interessante se pensarmos sobre a relação entre CV e GB coloniais. António Tomás explica esta relação de modo seguinte: 
(...) os cabo-verdianos continuaram [depois da criação da Guiné Portuguesa em 1879] a «colonizar» a Guiné, antes de mais por causa da língua. Em todas as outras colónias portuguesas, a colonização dependia, grosso modo, da criação de uma casta crioula nativa que servia de intermediária entre os colonos brancos e a grande massa de colonizados. Na Guiné tinha-se passado de outro modo. Os cabo-verdianos tinham-se imiscuído e formado, eles próprios, este grupo intermédio. Ao difundirem o seu próprio crioulo, que rapidamente se tornou língua franca, tornaram-se indispensáveis no elo entre portugueses e nativos.

Desta maneira, os cabo-verdianos tomavam conta de toda a vida da província (...) Portugal podia assim contar com uma categoria de colonos subalternos (...) criou-se uma elite instruída (...) (Tomás, 2007, p. 36-37).

Se o caso anterior, de um africano com canudo, pode ridicularizar tanto os colonialistas, que trazem algo alheio à realidade onde vêm parar, como os indígenas, que haveriam-de aceitar esses modelos, numa BD emancipadora não podiam ter faltado também caricaturas dos próprios colonizadores, feitas como se fossem caricaturas da imprensa. Lembremos que a BD contemporânea tem as suas raízes na caricatura da imprensa dos séculos XVIII e XIX. Sendo assim, os autores de Nô Pintcha abrem o leque de soluções da BD que criam, estendendo a panóplia narrativa estética às visualizações fortemente simbólicas como é o caso de imaginar o colono como uma ave de rapina (Fig. 8). Esta visualização não é nada desfasada da forma como os indígenas viam os colonialistas já na primeira fase de contactos. Existem provas de pelo menos três maneiras de percebê-los: canibais (pois os capturados por eles nunca voltavam), um inimigo perigoso e aquele que procura vingar-se (Tymowski, 2017, p. 283-334).

No cenário linguístico supra-referido na educação colonial que não é aceite pacificamente no âmbito dos PALOP, a BD Nô Pintcha parece realizar o conceito partilhado pelo angolano Luandino Vieira e moçambicano Samora Machel que alegaram que português é o troféu de guerra, uma metralhadora do colonizador virada contra ele para atirar da arma dele, mas com as balas africanas (Rzewuski, Lipszyc, 2012, p. 395-396), ou seja, a língua pode ser do colonizador, mas as ideias já são dos emancipados. É tentador comparar este tipo de reviravolta da ordem póscolonial com o antropofagismo cultural brasileiro de Mário de Andrade (www): o conteúdo fica recriado, domesticado, transforma-se. Nesta tradução de ideias o que se mantém intacto, é o signo, a portadora da ideia, isto é, a língua, mas a semântica torna-se diferente tal como o queria Haroldo de Campos nos moldes tradutológicos de transcriação baseada no rito antropofágico de devorar, transformar e devolver (Campos, 2016, p. 26-36). Numa BD que fala sobre a educação, vista por muitos como um dos factores da emancipação, e negada ou concedida aos escolhidos para não despertar a consciência do povo oprimido, a metáfora da metralhadora e das balas torna-se vibrante e condiz com a ideia de alfabetização como luta que já tínhamos referido antes (Fig. 9). Neste contexto não pode faltar na BD em questão Amílcar 
Cabral, "o fazedor de utopias" (Tomás, 2007), por nós já referido no contexto de resistência do povo oprimido (Fig. 10).

A resistência e luta visavam combater as velhas práticas que eram vistas como o resultado da colonização branca. Os autores de NôPintcha fazem um breve resumo da história colonial onde através de uma série de imagens simbólicas ilustram a tragédia dos escravizados. A estrutura de uma BD possibilita recorrer aos símbolos visuais fortes que exprimem mais do que podem expressar mil palavras. Eis o caso, p.ex., de um tumbeiro (Fig. 11) que servia para o transporte dos escravos. Este desenho simbólico fora da sequência narrativa pode ser ilegível (antecede-o uma imagem de um barco negreiro e um texto que tudo ajudam a explicar), mas de certeza é legível para quem uma vez estudou o fenómeno de tráfico de escravos. Logo a seguir da imagem do tumbeiro podemos ver um mapa com um esquema de transporte de escravos simplificado (Fig. 12).

Porém, entendemos que a violência do colonizador não é a única que existe neste cenário de tensão entre o oprimido e opressor. A resistência dos oprimidos revela-se em força na cena de expulsão do opressor para longe (Fig. 13), ou seja, de volta para Lisboa. A linguagem concisa e convencional de BD possibilita conter esta expulsão numa imagem só. Mas vejamos que a própria imagem tem contorno alongado, é um rectângulo que torna a cena contada nos moldes panorâmicos. Pela forma sublinha-se a distância entre a GB e Lisboa, e a vontade muito forte de expulsar os portugueses bem para longe. A dinâmica de cena é sublinhada pelas speed lines e estrelinhas que mostram a violência do acto. Porque é que se chegou a este ponte nas relações entre a GB e A Metrópole? Uma das razões é de certeza do sistema criado pelo opressor. Entre várias características do ensino na GB como a parte do Ultramar Português, mostra-se em NôPintcha a selectividade do ensino (destinado só para alguns, o que ilustra o desenho de um funil onde caem muitos, mas saem poucos - Fig. 14) que visava criar uma classe do guineense que pudesse exercer funções para servir ao colonizador-director, mas que nunca chegasse a comandar ou ocupar o topo da pirâmide social guineense (Fig. 15).

O triângulo social „Os ricos em cima... o povo em baixo” mostra quem suporta a estrutura do sistema colonial: este sustenta-se nos braços dos oprimidos curvados sobre o peso de vários opressores. Se os oprimidos decidirem levantar-se, desestabilizam a estrutura. Se se decidirem ir embora, a estrutura cai. A estrutura organizacional de uma sociedade colonial imaginada desta forma relembra diferentes visualizações triangulares com as quais se pode estabelecer ligações significativas e sugestivas. Por exemplo, o triângulo de Anderson/Krathwohl que mostra como se fomenta o raciocínio crítico (Fig. A). A base é "lembrar-se" e logo a seguir encontramos o nível de "entender". Transpondo esses dois níveis para o nível do povo do esquema apresentado em NôPintcha, podemos sugerir que o povo vai lembrar-se para sempre do jugo colonial (por isso o difícil é "descolonizar a mente") e quando 
entender bem a sua situação, vai-se levantar e sair deste esquema, vai aplicar o pensamento criativo. Assim o sistema vai cair e possibilitar-se-á as seguintes etapas já no esquema livre da opressão colonial que acabarão na criação de algo novo, por exemplo, na criação de um novo sistema educacional.

Esta visão triangular pode remeter-nos ainda ao triângulo de McCloud que, para mostrar como funciona a técnica de cartoon na $\mathrm{BD}$, criou o esquema triangular que como a base tem pontos de realidade (toda a BD que se situa perto deste ponto, recorre a linguagem imagética realista) e significado (toda a BD que se situa perto deste ponto, recorre a linguagem imagética simbólica até ultrapassar a linha fronteiriça - uma vez passada, as apresentações tornam-se textuais), e como o terceiro ponto, em cima, tem o "picture plane", o mais abstracto (toda a BD que se situa perto deste ponto, recorre a linguagem imagética figurativa). $\mathrm{O}$ interessante é que se subirmos pelos lados que saem dos pontos realidade e significado para cima, chegamos a uma área totalmente abstracta, que pouco tem a ver as apresentações reais (McCloud, 1995, p. 52-53). Agora vejamos quem está em baixo e que em cima na apresentação esquemático-simbólica em NôPintcha? Respectivamente o povo e o governo colonial, o real e o simbólico contra o abstracto.

Como já percebemos, o sistema do ensino introduzido pela Metrópole visava sobretudo colonizar a mente do colonizado, de criar uma mentalidade com efeitos duradouros. Na já mencionada série Racismo em Português os entrevistados apontam para este fenómeno perigoso que ainda continua p.ex. em Angola. O título da reportagem diz tudo: „Independência sem descolonização das mentes” (Gorjão Henriques, 2016, p. 19-53). Embora NôPintcha fale sobre GB, os fenómenos que toca, referem-se a todos os países participantes do $1 .^{\circ}$ encontro dos educadores. Openess referencial gera-se neste aspecto ao nível comunitário de todos os PALOP pertencentes a Ultramar Português. Ou seja, o mesmo fenómeno existe em todos os PALOP e continua a ter efeitos hoje em dia. Outra vez os autores da BD em questão recorrem à metáfora deste processo da colonização das mentes, mas desta vez mostrada numa sequência cujo resultado é uma hibride de um indígena com a mão do opressor que lhe indica o caminho (Fig. 16). Esta mão que aponta o caminho desaparece parcialmente com o colonizador expulso e o indígena desorientado acaba por encontrar-se num cavalo (Fig. 17), ou seja, não sabe bem o que fazer.

A questão da selectividade do ensino não acabava com a educação no lugar, na colónia. O sistema na GB funcionava como o filtro e a "desafricanização" completava-se na Metrópole onde, segundo a metaforização de NôPintcha, trocava-se cabeças africanas pelas cabeças portuguesas, ou seja, formava-se agentes do regime opressor (Fig. 18). É preciso acrescentar que p.ex. a Casa dos Estudantes do Império, da qual entre outras instituições aqui se fala, acabou por criar, para além dos escravos mentais da metrópole, também aqueles que mudaram o futuro das suas pátrias, entre eles Amílcar Cabral (Rosas, 1997, p. 13-21). Mas, regra geral, o negro 
passava a vestir máscara branca. O processo de colonizar as mentes tem moldes que Abdulai Sila, escritor guineense, chama um dos aspectos mais violentos do colonialismo que "era despir as pessoas completamente, [era] aquilo que Frantz Fanon chamou «pele negra, máscaras brancas»" (apud Gorjão Henriques, 2016, p. 72). NôPintcha usa "przerysowanie" para o mostrar sem rodeios nenhuns.

Mais uma manifestação de aceitar as regras do jogo europeias, de vestir uma máscara, encontramos quando se constata que não se sabia na GB nada sobre a África fora das fronteiras, nada "fora da tabanca". É interessante apontar neste aspecto mais uma vez às situações um tanto absurdas de hoje em dia, quando os cidadãos dos PALOP reparam com a realidade em que num país africano não é possível comprar nem um mapa de África (Gorjão Henriques, 2016, p. 108).

O sistema colonial deixou muitos problemas por resolver, todos eles nos caixotes fechados (Fig. 19). A metáfora da situação da GB, onde um homem desorientado a cavalo não sabe o que fazer e como prosseguir, de uma certa forma repete-se na estrutura narrativa: um caixote fechado não expõe o que tem dentro, o novo guineense não sabe o que encontrará ao abrir caixotes seguintes, quase tudo é enigmático e incerto. $\mathrm{O}$ colonizador pôs tudo seu nos caixotes que voltaram para Portugal com os retornados, tal como o fez em Angola (Kapuściński, 2013, p. 30-38), deixando atrás apenas os caixotes cheios de problemas.

Mais um questão que se manifesta em força em Nô Pintcha, é a relação imagempalavra. Esta surge como extremamente importante porque a mensagem nasce de uma sábia combinação dos dois que ironiza o conteúdo, ou seja, não é suficiente perceber o conteúdo imagético, pois o código verbal o complementa. Na tipologia de McCloud esta ligação podemos classificar como aditiva, ou seja, nela "as palavras ampliam ou elaboram sobre uma imagem" (McCloud, 1995, p. 154).

O exemplo que passamos a comentar (Fig. 20) é uma boa prova disso. A pessoa desta imagem que está no meio transporta às costas um bebé. A pessoa da esquerda, esta cujas mãos vemos como se à tona do (provavelmente) arroz por onde andam todos (será uma família?) a transportar algo nos cestos colocados sobre cabeças, é evidentemente uma criança. Em total temos duas pessoas adultas e duas crianças nas idades diferentes, talvez uma família cujos membros aprendem trabalhando. O texto diz-nos que "trabalho e escola não eram duas coisas separadas", põe-se o signo de igualdade entre a escola e a vida o que está em sintonia com as ideias que segundo Freire deviam ser adaptadas ao novo ensino. Um texto sério entra em relação com a imagem e acrescenta-lhe uma explicação que não é directa. Pois o texto não repete o conteúdo imagético, é antes aberto a vários conteúdos imagéticos que o podiam ilustrar/contrapor/interpretar etc. Aqui, na tensão texto vs imagem (Hatfield, 2005, p. 36-41) ocorre um openess típico já ao nível do processo criativo (e só depois na ligação que o leitor irá fazer entre dois códigos): como ilustrar um texto desses para produzir uma resposta produtiva do leitor? Como activar o leitor na recepção deste conteúdo? Como não lhe dar respostas prontas? 


\section{CONCLUSÃO}

A lista de temas, questões e aspectos característicos para a filosofia de Freire, todos eles interligados entre si, que encontramos em Nô Pintcha, compreende:

- elementos de filosofia que destacam a ligação entre homem, história e educação ("A nossa história começa numa escola da Guiné-Bissau");

- interligação entre a educação universal para crianças e adolescentes com a educação popular dos adultos;

- unificação da educação com trabalho visto como o processo de transformação do mundo;

- presença de temas generativos (tarefas da aritmética sobre o cultivo de arroz e a procriação dos mosquitos) como o ponto central de referência à educação;

- teoria de interesses e de política de vozes exemplificada nas questões gender e na discriminação da mulher antes e hoje;

- crítica das formas tradicionais (europeias?) de conhecimento e de pensar sobre o mundo (um belo anti-centrismo à McArthur, Fig. B);

- a colonização vista como um empreendimento militar e a celebração da resistência frente a mesma;

- carácter comercial da colonização exemplificado através do tráfico transatlântico negreiro e da exploração económica da colónia;

- crítica do papel da escola na sociedade colonial que realiza o interesse económico dos privilegiados à sombra da missão civilizadora;

- a concepção bancária da educação com o fim de colonizar as mentes, assimilação e criação dos pretos com cabeças brancas;

- a crítica da sociedade colonial de classes movimentada pela sequência de violência que petrifica estruturas sociais;

- problemas de educação colonial transpostos à situação póscolonial: acesso restrito, papel selectivo do ensino, criação do sistema superioridade/inferioridade, desligação da escola dos problemas sociais;

- a questão de reformar o sistema educacional (metáfora do cavaleiro e do cavalo).

No sistema de raciocinar de Freire todos os elementos que acabamos de listar, interligam-se entre si, por isso a análise desses no livro Nô Pintcha podíamos ter começado por qualquer um. $\mathrm{O}$ autor da $\mathrm{BD}$ em questão começou-a, por sua vez, consciente ou inconscientemente, com as seguintes palavras - "A nossa história começa numa escola da Guiné-Bissau" - o que nos logo remete à historiosofia freirense. Pode não ser o início da história no entendimento de Hegel, mas de certeza é o início de um novo capítulo na história do Povo Guineense. O momento quando surge esta $\mathrm{BD}$ e o momento sobre o qual fala, podemos identificar com o momento de "emersão das massas populares" (Freire, 1983, p. 27) e a sua "inserção na História" (Freire, 1967, p. 36). Estamos a referir-nos ao momento em que cresce 
o leque de oportunidades quanto à autodeterminação, em que os oprimidos emancipam-se dos limites impostos até à altura pelos opressores privilegiados que acabam de perder o poder decisivo. Não se pode, porém, falar sobre a independência total da herança colonial e dos múltiplos problemas sociais, como se no-lo mostra na BD Nô Pintcha (páginas 17-26).

A BD Nô Pintcha realiza pressupostos da historiosofia freirense na qual o homem faz parte integral do processo histórico (Freire, 1983, p. 32), ele permance no "jôgo dialéctico" «eu» e «não-eu» (Freire, 1983, p. 52), o que se descreve também como "um jogo interactivo de actuar/pensar sobre o/no mundo" (Freire, 1979 , p. 8). Esta interpretação vem apoiada pelo desfecho aberto (mais uma realiação de openess) que sugere o projecto de uma nova escola como a prática em aberto, privada de soluções prontas, mas ao mesmo tempo pesa sobre ela a herança histórica. Vemos aqui as relações dialécticas entre a unidade e a comunidade, entre o homem e o mundo, entre o passado e o futuro. Quanto a este precioso momento histórico e contexto social podemos ver ainda o que nos diz Francisco Weffort na introdução do livro Educação como prática da liberdade:

$\mathrm{O}$ educador, preocupado com o problema do analfabetismo, dirigiu-se sempre às massas que alguns supunham «fora da história». O educador, a serviço da libertação do homem, dirigiu-se sempre às massas mais oprimidas, acreditou em sua liberdade, em seu poder de criação e de crítica (Weffort, 1967, p. 26).

Os conteúdos supra-comentados inscrevem-se no conceito de openess tanto no nível da estrutura da $\mathrm{BD}$ em questão, como na mensagem dela. A característica geral da ferramenta analítica por nós aceite consiste numa relação interactiva de processo interpretativo entre o leitor e o texto (Ahmed, 2016, p. 4), o que possibilita referenciar intertextualidades (sugestividade) tanto temporais, como geográficas, sendo ambos os tipos circunscritos ao contexto africano colonial e póscolonial. Como diz Ahmed, Eco tenta "point out that the haphazard or incomplete structure reflects a particular notion of the world as «a web of possibilities». The work in movement is therefore an essentially modern product reflecting changed conceptions of the world including, for instance the emergence of relativity and the uncertainity principle in the realm of science" (Ahmed, 2016, p. 5). Entendemos então que a nossa releitura dos artefactos históricos como NôPintcha não só pode, mas tem de funcionar numa grelha de duplo carácter dia- e sincrónico, circunscrito ainda à ordem colonial/póscolonial das referências e a uma análise estrutural do meio em que algo é nos contado. 


\section{BIBLIOGRAFIA}

Achebe, Ch. (1989/2012). Polityka i politycy języka w literaturze afrykańskiej. Edukacja dziecka pod brytyjskim nadzorem. Trad. de J. Łoziński. Poznań: Zysk i S-ka.

Ahmed, M. (2016). Openess of Comics. Generating Meaning within Flexible Structures. Jackson: University Press of Mississippi.

Andrade, O. de (1924/1928). Manifesto antropófago e Manifesto da poesia pau-brasil. Recuperado de www.ufrgs.br/cdrom/oandrade/oandrade.pdf.

Assumpção, R. (Ed.) (2009). Educação popular na perspectiva freirana. São Paulo: Ed,L.

Beaty, B. (2013). Komiks kontra sztuka. Trad. por A. Kaczmarek e M. Cieślik. Warszawa: Timof Comics.

Biesta, G. (2010). A new logic of emancipation. The methodology of Jaques Rancière. Educational Theory, 60 (1), 39-59.

Brandão, C.R., Assumpção, R. (Eds.) (2009). Cultura Rebelde. Escritos sobre a Educação Popular ontem e agora. São Paulo: Ed,L.

Brzezińska, M. (2014). W cieniu europejskiej twierdzy. Obrazy zachodu w dyskursach mieszkańców Gwinei Bissau. Tese de doutoramento orientada pelo professor doutor M. Ząbek. Warszawa: Uniwersytet Warszawski, Wydział Historyczny, Instytut Etnologii i Antropologii Kulturowej.

Brzezińska, M. (2017). W cieniu europejskiej twierdzy. Obrazy zachodu w dyskursach mieszkańców Gwinei Bissau. Warszawa: WUW.

Campos, H. de (2016). Tradycja, transkreacja, transkulturacja: eks-centryczny punkt widzenia. Trad. por G. Borowski. Przekladaniec. A Journal of Translation Studies, 33, 26-36.

Dowbor, L. (2016). Jak Partia Pracujących zmienita Brazylię (entrevista conduzida por J. Petelczyc; 21-38). Trad. de W. Henschel. Warszawa: Książka i Prasa.

Eiró, F. (2016). Program «Bolsa Familia» w centrum uwagi: ubóstwo, klientelizm i obywatelstwo (entrevista conduzida por J. Petelczyc; 39-55). Trad. de W. Henschel. Warszawa: Książka i Prasa.

Foucault, M. (2009). Security, Territory, Population: Lectures at the Collège de France, 1977-1978. New York: Palgrave Macmillan.

Freire, P. (1967). Educação como prática da liberdade. Rio de Janeiro: Paz e Terra, dhnet.org.br/direitos/militantes/paulofreire/livro_freire_educacao_pratica_liberdade.pdf.

Freire, P. (1978). Cartas aos Animadores e às Animadoras Culturais. São Tomé: Ministério de Educação Nacional e Desporto.

Freire, P. (1979). Educação e Mudança. São Paulo: Paz e Terra, dhnet.org.br/direitos/ militantes/paulofreire/paulo_freire_educacao_e_mudanca.pdf.

Freire, P. (1983). Extensão ou Comunicação. Rio de Janeiro: Paz e Terra, forumeja.org. br/files/Extensao_ou_Comunicacao1.pdf.

Freire, P. (1994). Pedagogia do Oprimido. Rio de Janeiro: Paz e Terra, dhnet.org.br/direitos/ militantes/paulofreire/paulo_freire_pedagogia_do_oprimido.pdf.

Freire, P. (2000). Pedagogia da indignação. São Paulo: UNESP, dhnet.org.br/direitos/militantes/ paulofreire/paulo_freire pedagogia_da_indignacao.pdf.

Freire, P., Faundez, A. (1998). Por uma pedagogia da pergunta. Rio de Janeiro: Paz e Terra, dhnet.org.br/direitos/militantes/paulofreire/paulo_freire_por_uma_pedagogia_da_pergunta.pdf.

Frey, N., Fisher, D. (Eds.) (2008). Teaching Visual Literacy. Thousands Oaks: Corwin Press.

Gadotti, M. (2009). Educação de Adultos como Direto Humano. São Paulo: Ed,L.

Gadotti, M. (Ed.) (1996). Paulo Freire. Uma biobibliografia. São Paulo: Cortez and Instituto Paulo Freire. 
Gerhardt, H.P. (1996). Arqueologia de um Pensamento. In M. Gadotti (Ed.), Paulo Freire. Uma biobibliografia (pp. 149-170). São Paulo: Cortez and Instituto Paulo Freire.

Giroux, H.A. (2001). Theory and Resistance in Education. Towards a Pedagogy for the Opposition. Westport/London: Bergin \& Garvey.

Gorjão Henriques, J. (2016). Racismo em português. O lado esquecido do colonialismo. Lisboa: Tinta-da-China.

Harasim, L. (1983). Literacy and National Reconstruction in Guinea Bissau: A Critique of the Freirean Literacy Campaign. Toronto: University of Toronto.

Hatfield, Ch. (2005). Alternative Comics. An emerging literature. Jackson: University Press of Mississippi.

Hlibowicka-Węglarz, B. (2013). Portugalskie języki kreolskie w Afryce. Lublin: Wydawnictwo Uniwersytetu M. Curie-Skłodowskiej.

Hodgson, N., Vliege, J., Zamojski, P. (2017). Manifesto for a Post-Critical Pedagogy. Earth: Punctum Books.

Hooks, B. (1993). Bell Hooks Speaking about Paulo Freire - the Man, his Work. In P. McLaren, P. Leonard (Eds.), Paulo Freire: A critical encounter (pp. 146-154). London/New York: Routledge.

Janicki, B. (2016). Dydaktyczny potencjat komiksu historycznego. Opole/Poznań: Zin Zin Press.

Jankowski, J. (2017). Rozumiejąc przekład. Czy «Zrozumieć Komiks» Scotta McClouda $\mathrm{i}$ «Understanding Comics. The Invisible Art» Scotta McClouda to ten sam komiks? Zeszyty Komiksowe, 23, 62-78.

Jankowski, J. (2018). Diabeł tkwi w szczególe, rynnie czy między kadrami? Czyli o polskim przekładzie McClouda raz jeszcze. Zeszyty Komiksowe, 25, 90-101.

Latour, B. (2005). Reassembling the Social. An Introduction to Actor-Network Theory. Oxford: Oxford University Press.

Lent, J.A. (2011). Afrykańska sztuka komiksu i żartu rysunkowego: wymiar historyczny i współczesny. In G. Gajewska e R. Wójcik (Eds.), Kontekstowy MIKS. Przez opowieści graficzne do analiz kultury wspótczesnej (pp. 255-280). Poznań: Wydawnictwo Poznańskiego Towarzystwa Przyjaciół Nauk.

McCloud, S. (1995). Desvendando os quadrinhos. Trad. por H. de Carvalho e M. do Nascimento Paro. São Paulo: Makroon Books.

McLaren, P. (2000). Che Guevara, Paulo Freire and the Pedagogy of Revolution. Lanham: Rowman \& Littlefield.

Mafra, J. (2010). O ser humano integral e o humanismo científico de Suchodolski. In I. Wojnar, J. Mafra (Eds.), Bogdan Suchodolski (pp. 37-49). Recife: FJN/Massangana.

Mafra, J., Romão, J.E., Scocuglia, A.C., Gadotti, M. (Eds.) (2009). Globalização, Educação e Movimentos Sociais. 40 anos da Pedagogia do Oprimido. São Paulo: Ed,L.

„No Pinca”. Purmeru Kadernu di Alfabetisason na Portugis (1989). Bissau: Ministério da Educação da República da Guiné-Bissau.

Pereira, P. (1989). Experiência de Educação de Adultos na Guiné-Bissau. Bissau [falta da informação sobre a editora, mas deve-se tratar do Departamento de Educação de Adultos].

Rancière, J. (1991). The Ignorant Schoolmaster. Five Lessons in Intellectual Emancipation. Stanford: University Press.

Romão, J.E., Gadotti, M. (2012). Paulo Freire e Amílcar Cabral. A descolonização das mentes. São Paulo: Ed,L.

Rosas, F. (1997). A CEI no contexto da política colonial portuguesa. Mensagem (número especial), 13-21.

Rosas, F. (2018). História a história. África. Lisboa: Tinta-da-China. 
Rzewuski, E. (2012). Pięć rozwiedzionych żon poligamisty (entrevista conduzida por M. Lipszyc). Literatura na Świecie, 5-6, 376-397.

Stańczyk, P. (2018). Freirego Suchodolskim - Suchodolskiego Freirem: pedagogika materialistyczna i krytyka ideologii. Teraźniejszość - Człowiek - Edukacja, 2 (82), 7-30.

Szyłak, J. (2012). To świat sztuki jest gettem (entrevista conduzida por S. Frąckiewicz). Wyjście z getta. Rozmowy o kulturze komiksowej w Polsce (pp. 338-365). Warszawa: 40000 Malarzy.

Tomás, A. (2007). O fazedor de utopias. Uma biografia de Amílcar Cabral. Lisboa: Tinta-da-China.

Torres, C.A. (1993). From the Pedagogy of the Opressed to A Luta Continua: The Political Pedagogy of Paulo Freire. In P. McLaren, P. Leonard (Eds.), Paulo Freire. A critical encounter (pp. 119-145). London/New York: Routledge.

Torres, C.A. (1996). Uma biografia intelectual. In M. Gadotti (Ed.), Paulo Freire. Uma biobibliografia (pp. 117-148). São Paulo: Cortez and Instituto Paulo Freire.

Traczyk, M. (2017). Dopełnianie rynny. Na marginesie tekstu Jakuba Jankowskiego o polskim thumaczeniu Zrozumieć komiks Scotta McClouda. Zeszyty Komiksowe, 23, 80-85.

Tymowski, M. (2017). Europejczycy i Afrykanie. Toruń: Wydawnictwo Naukowe Uniwersytetu Mikołaja Kopernika.

UNSD (United Nations Statistics Division), https://unstats.un.org/home/ (19.12.2018).

Vlieghe, J. (2016). Rethinking emancipation with Freire and Rancière. A plea for a thing-centered pedagogy. Educational Philosophy and Theory, 50 (10), 1-11.

Weffort, F.C. (1967). Educação e Política. Reflexões sociólogicas sobre uma pedagogia da liberdade. In P. Freire, Educação como prática da liberdade (pp. 1-26). Rio de Janeiro: Paz e Terra.

Wertham, F. (1954/2009). Excerpt from Seduction of the Innocent. In J. Heer e K. Worcester (Eds.), A Comics Studies Reader (pp. 53-57). Jackson: University Press of Mississippi. 
ANEXO 1. Imagens de referência do livro NôPintcha

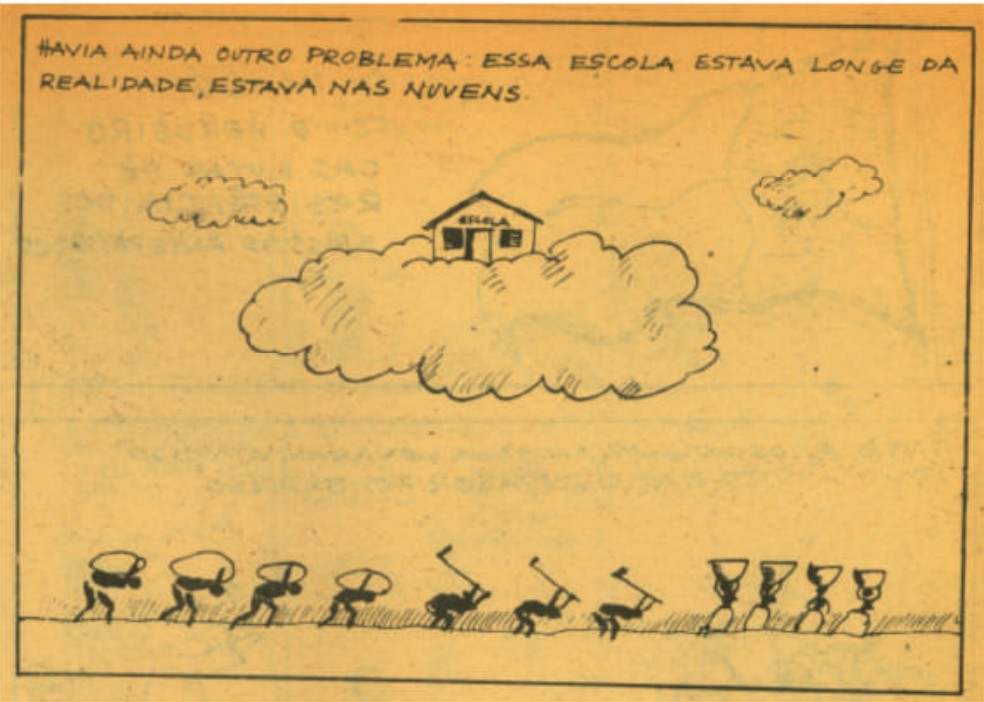

Fig. 1. "Escola nas nuvens"

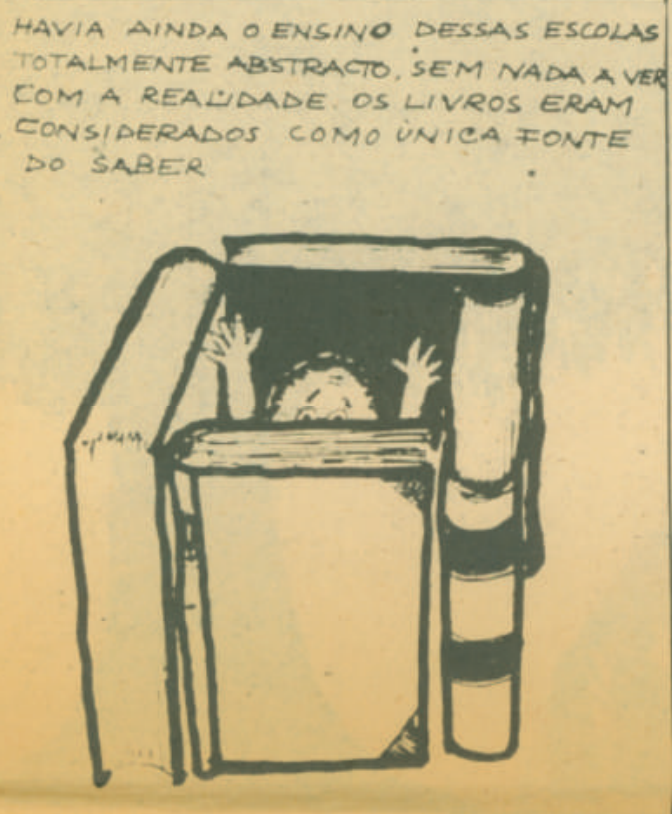

Fig. 2. Ensino-opressor entre livros-paredes de uma "prisão" 


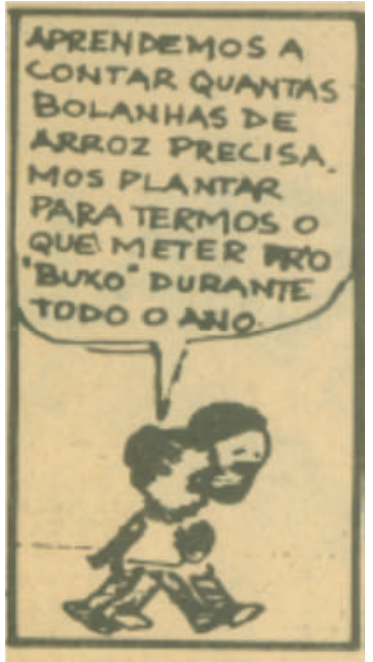

Fig. 3. Matemática com cultivo

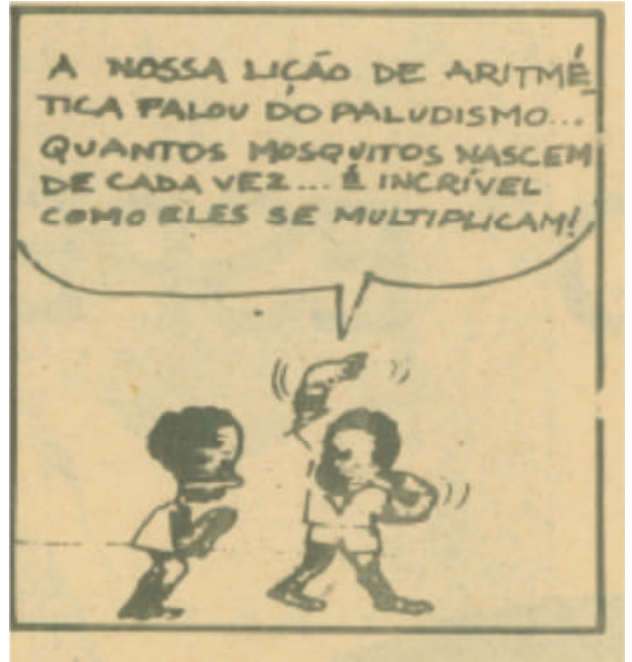

Fig. 4. Matemática com mosquitos

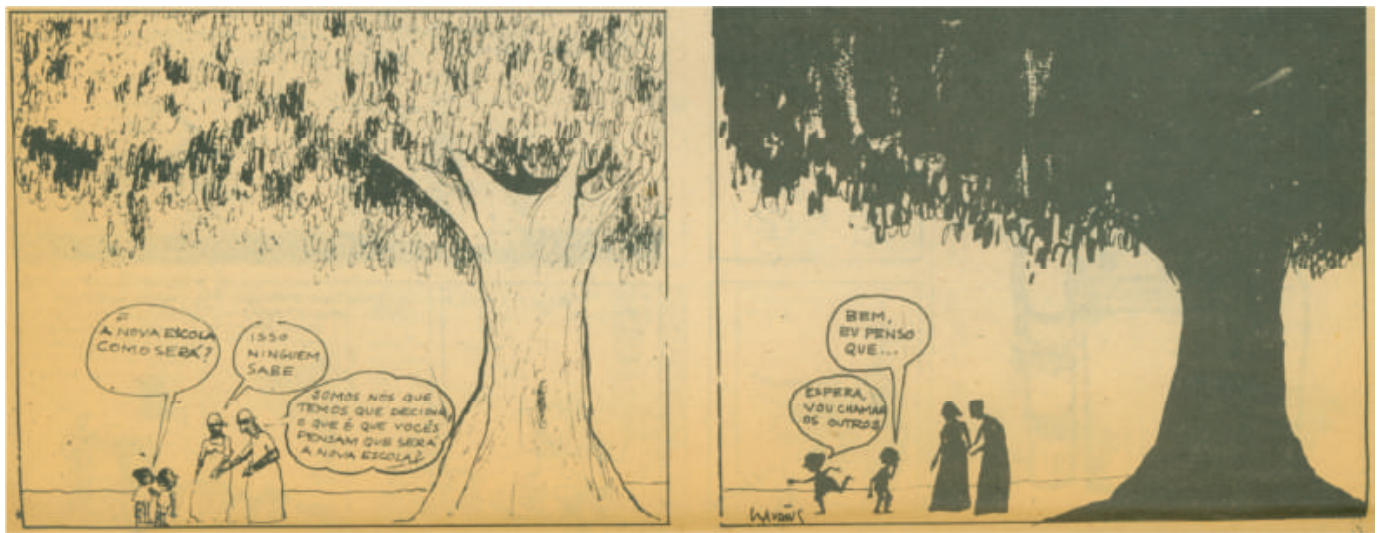

Fig. 5. A escola é na terra, não nas nuvens 


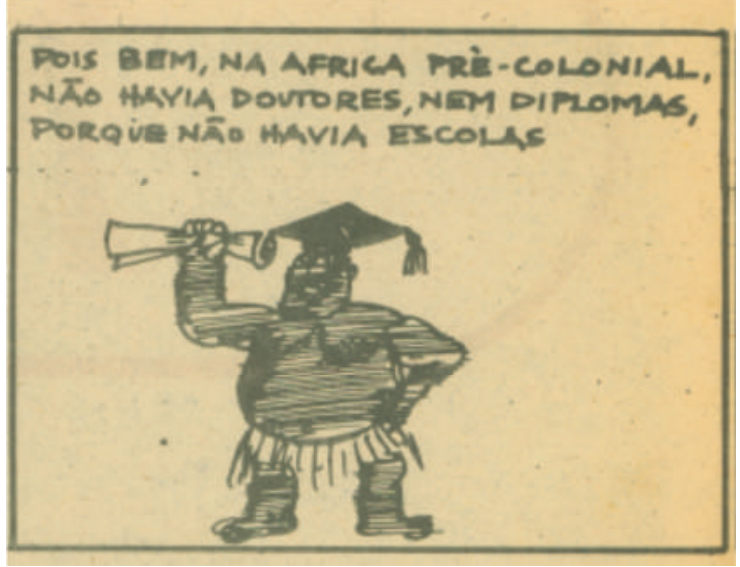

Fig. 6. A sugestividade na ordem textual-imagética

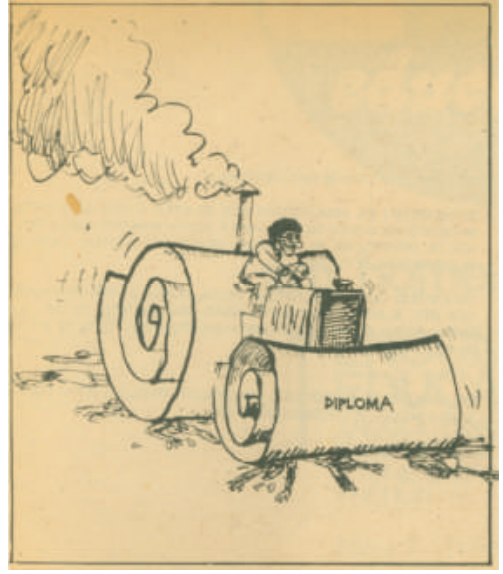

Fig. 7. "Máquina aplanadora-diplomática"

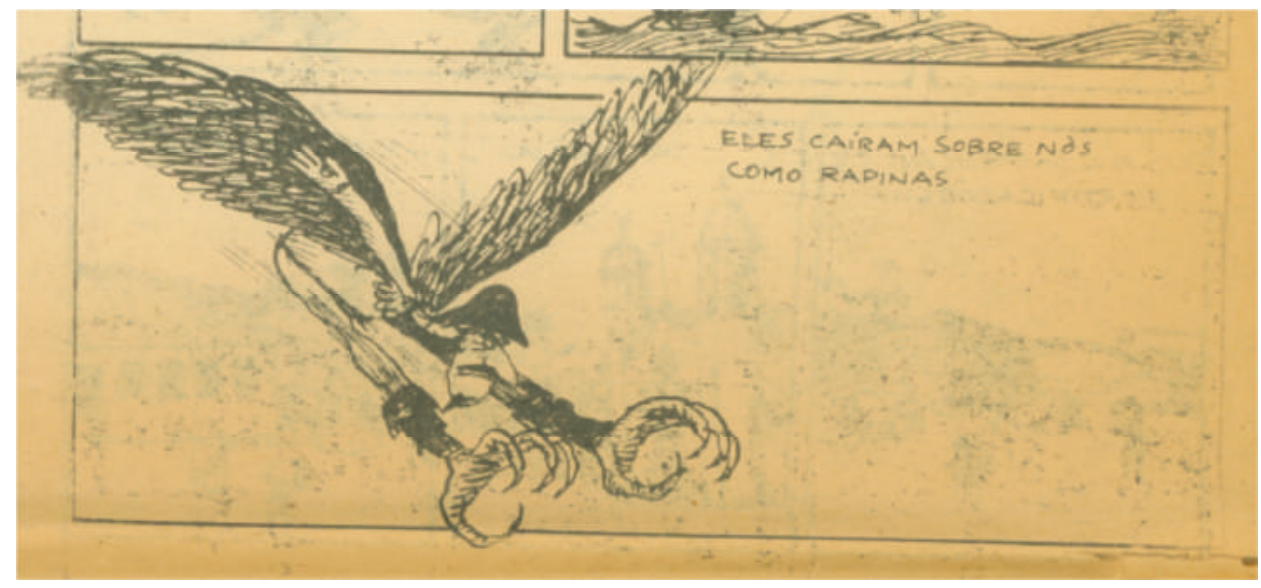

Fig. 8. Metaforização simbólica de "colonizador de rapina" 


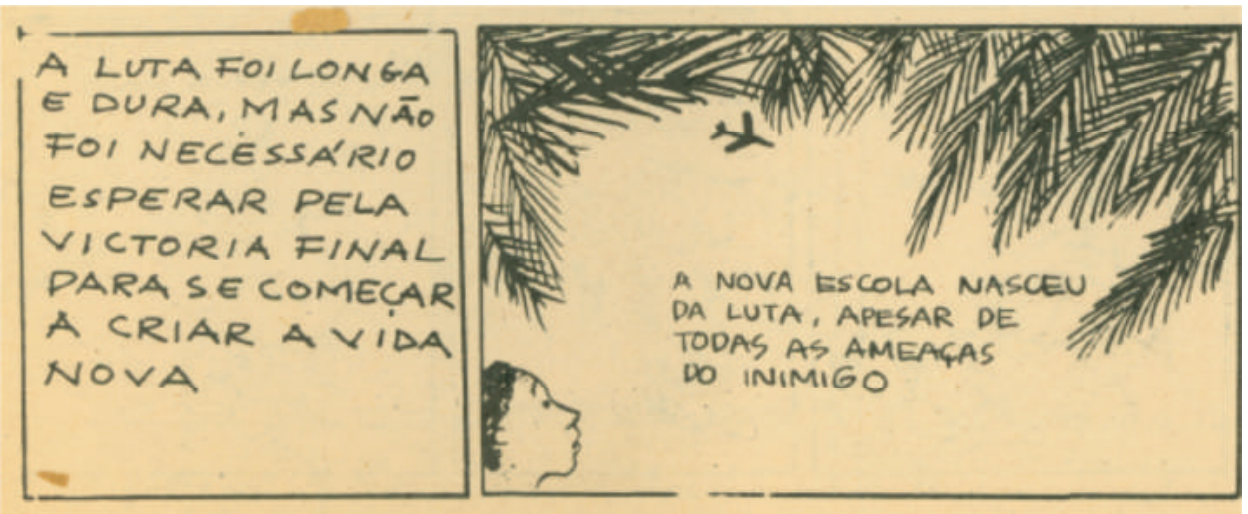

Fig. 9. A nova ordem nasce no processo da luta

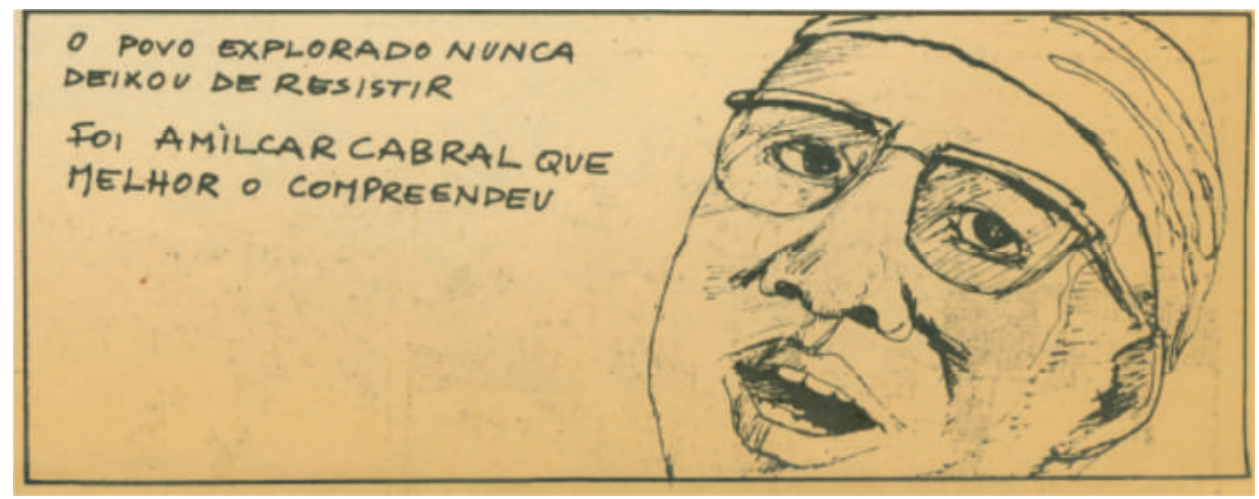

Fig. 10. Amílcar Cabral visualizado 


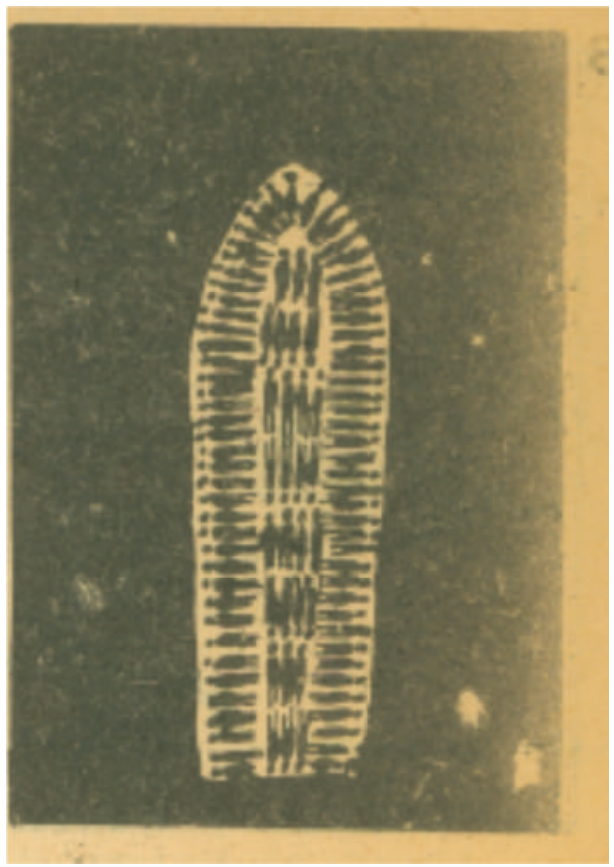

Fig. 11. Um tumbeiro visualizado

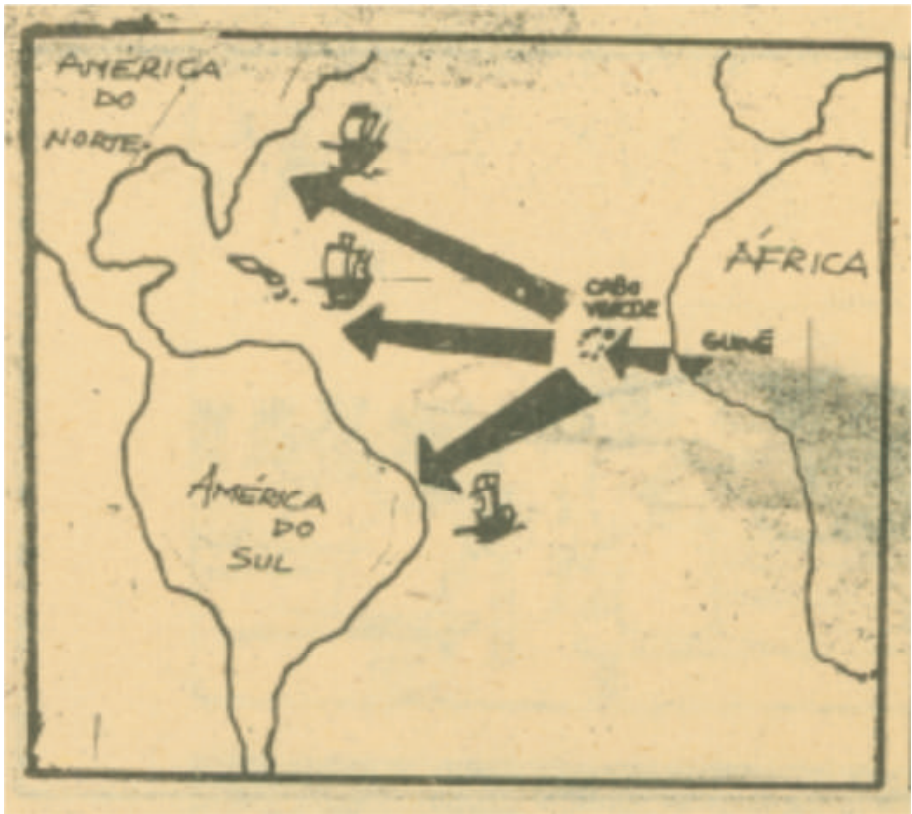

Fig. 12. Um esquema simplificado de rotas da esravatura 


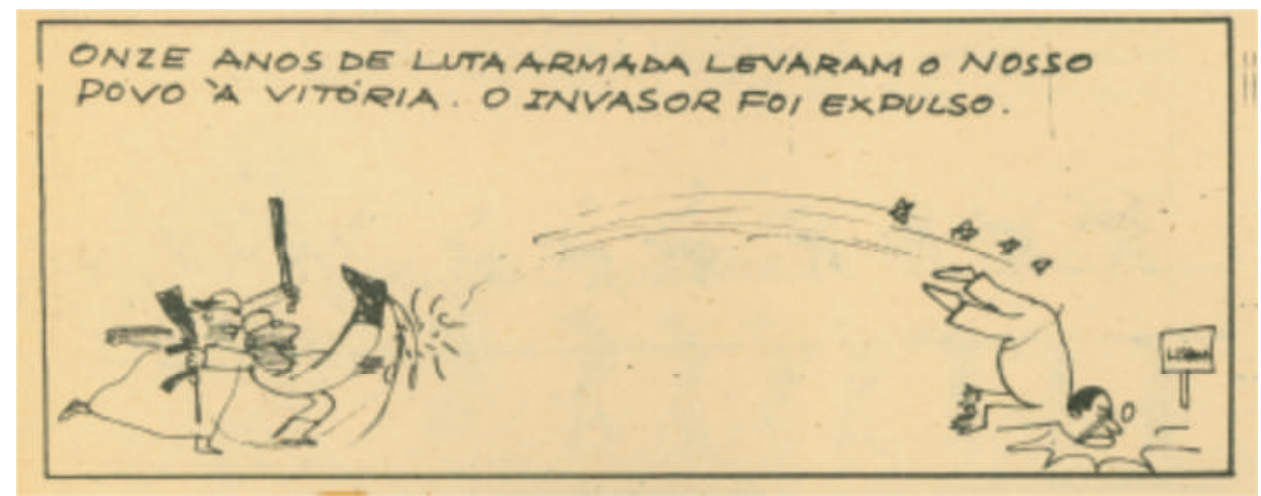

Fig. 13. Ergonomia da linguagem de BD, ou seja, como ilustrar de uma forma concisa

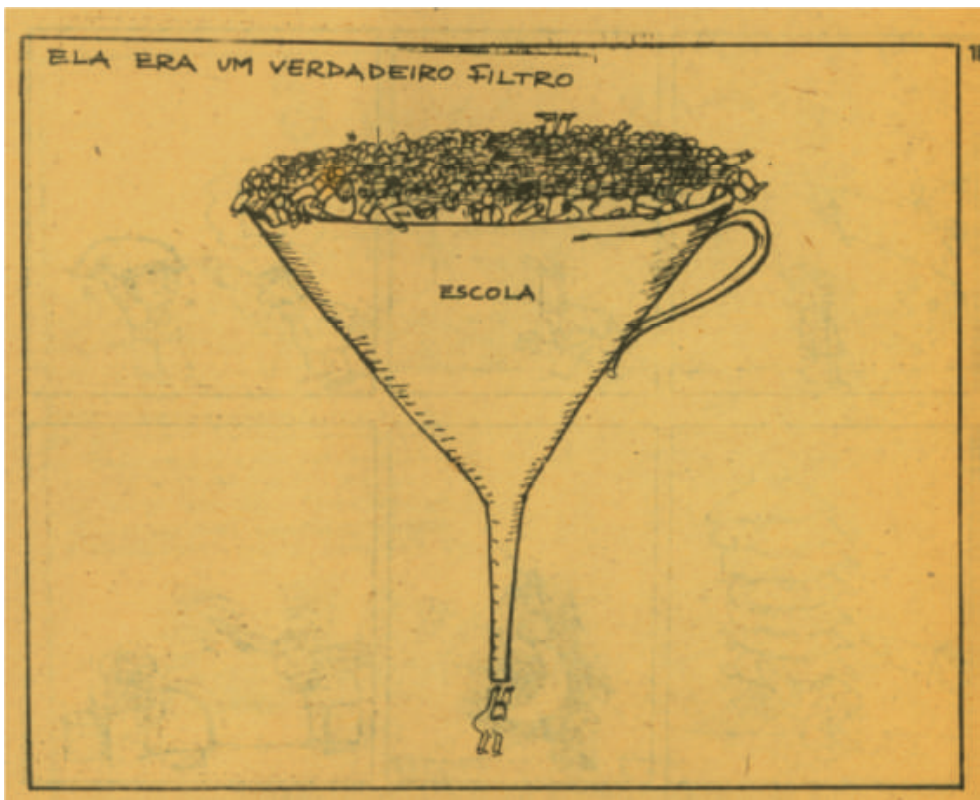

Fig. 14. Métafora da selectividade do sistema de educação colonial 


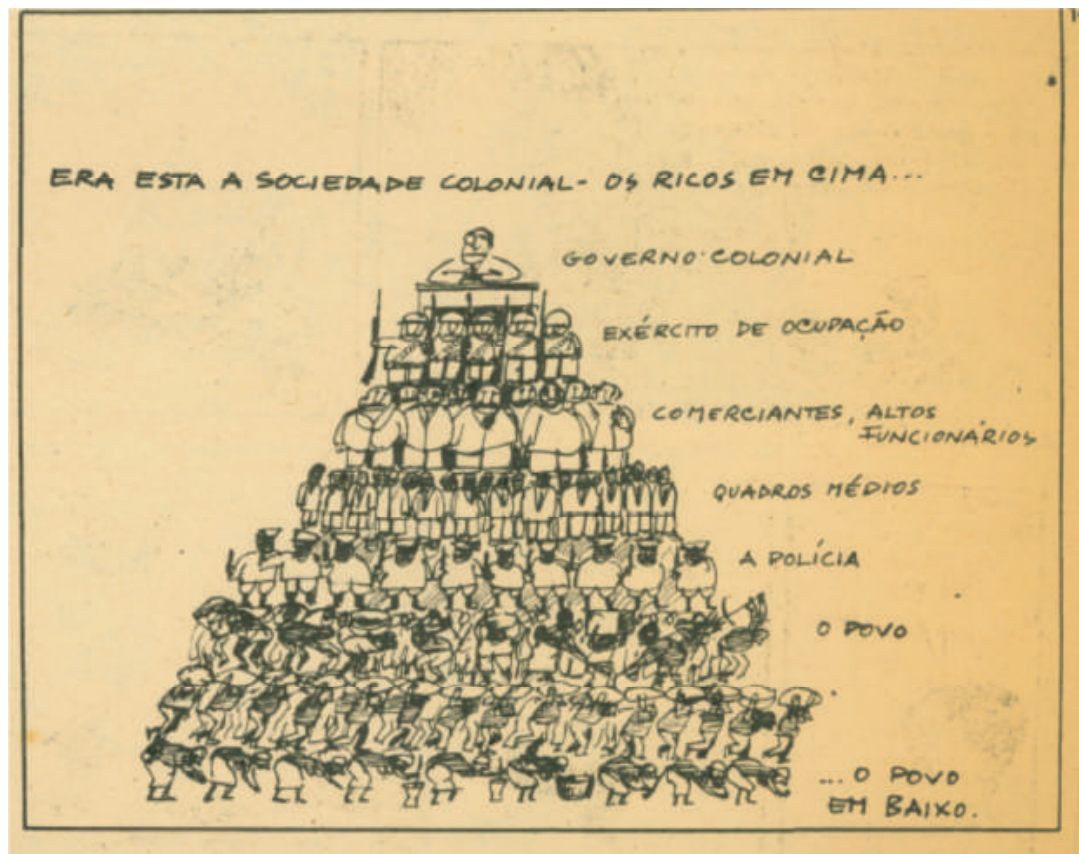

Fig. 15. Piramide social-colonial guineense
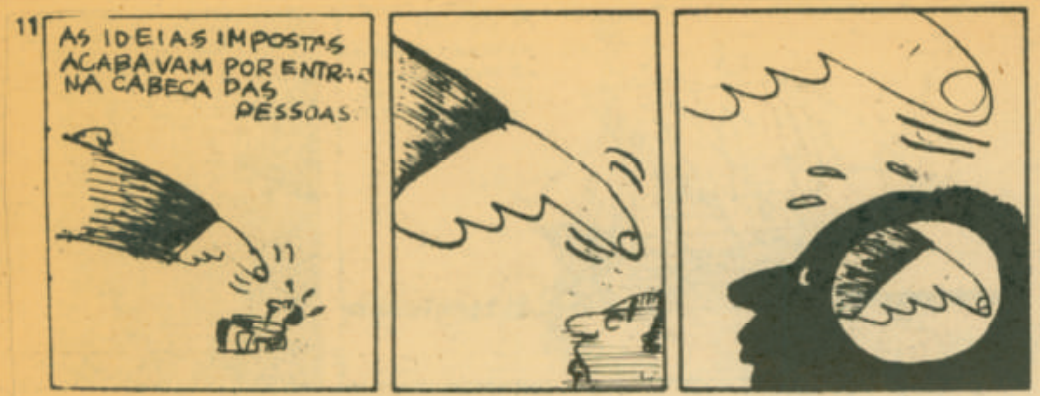

ERA A COLONIZACÃO DAS MENTES

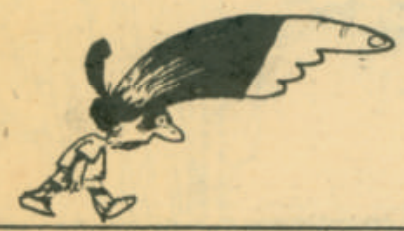

Fig. 16. A colonização das mentes metaforizada 


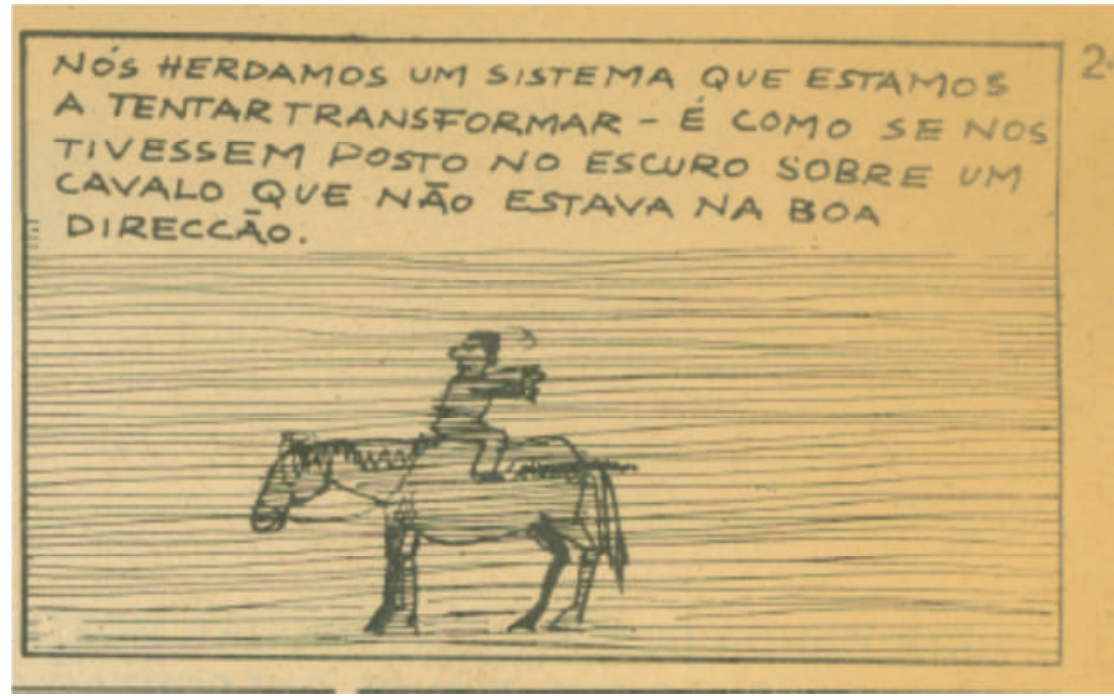

Fig. 17. Qual é futuro da educação na GB?
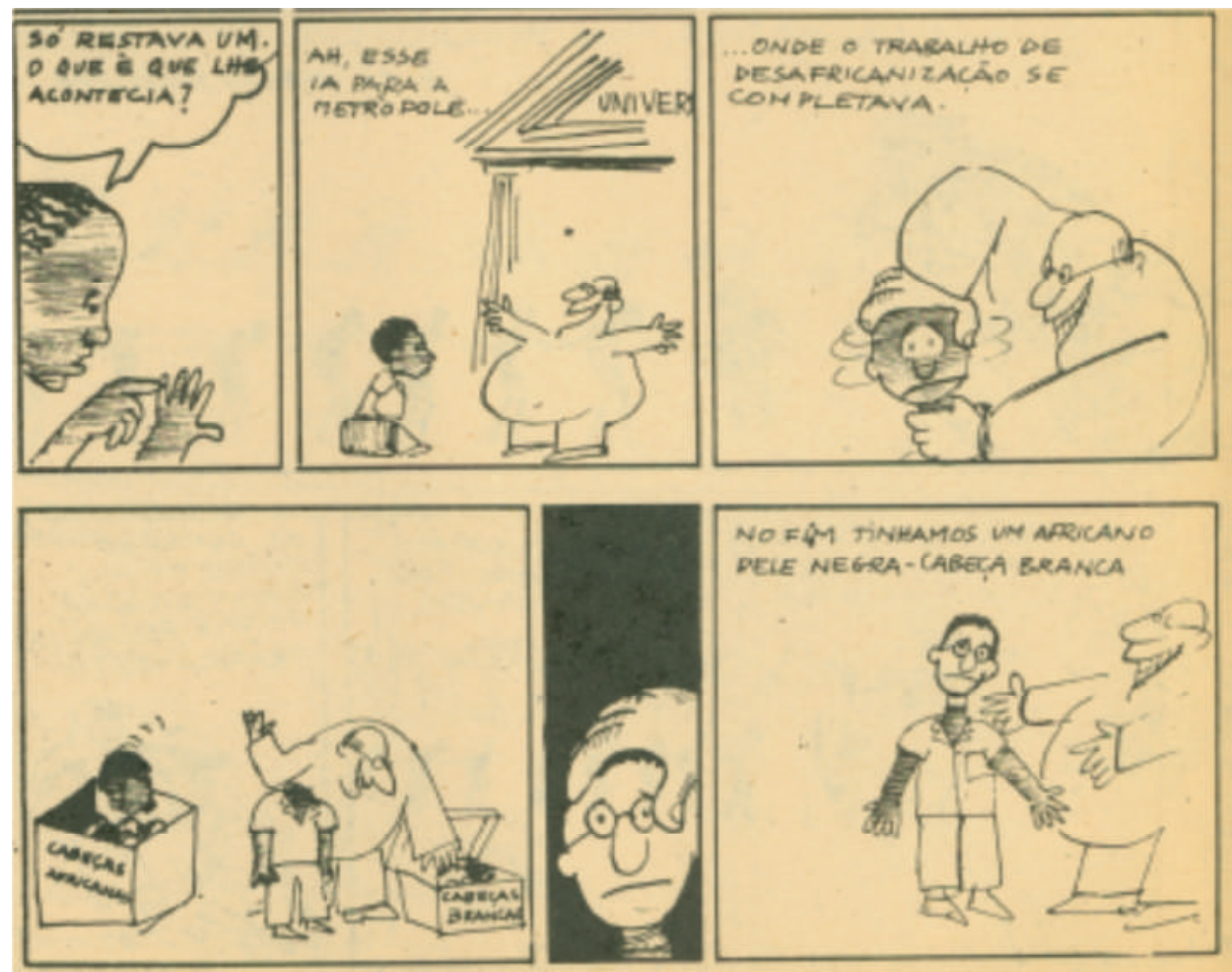

Fig. 18. Como criar um bom colonizado - "pele negra, máscara branca" 


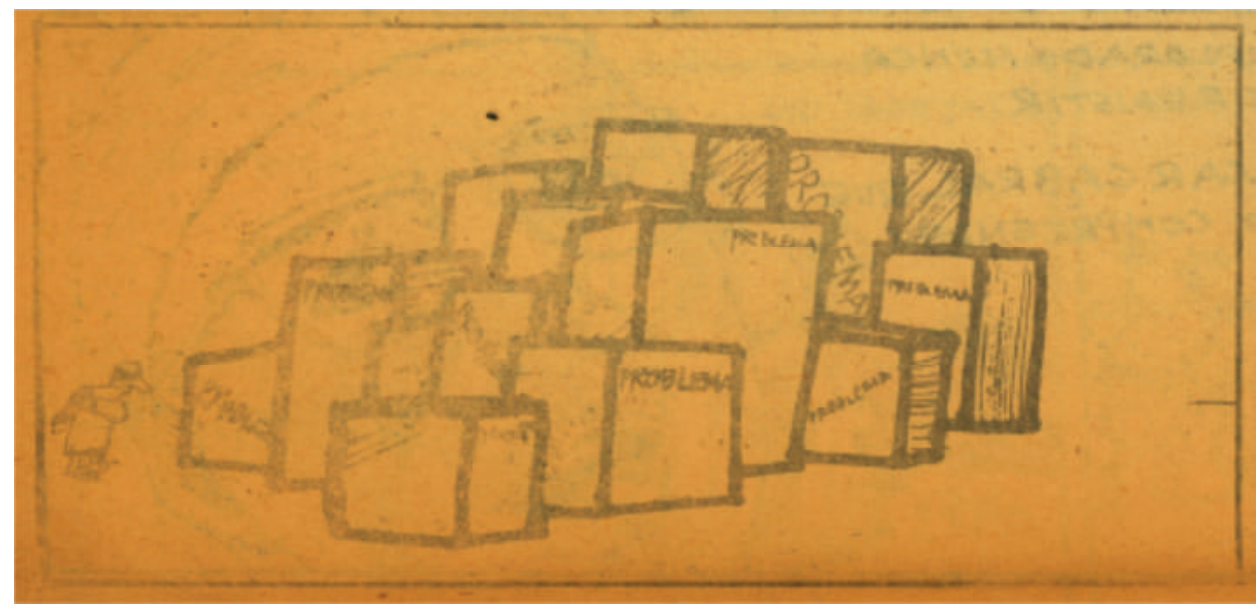

Fig. 19. A herança do sistema colonial empacotada

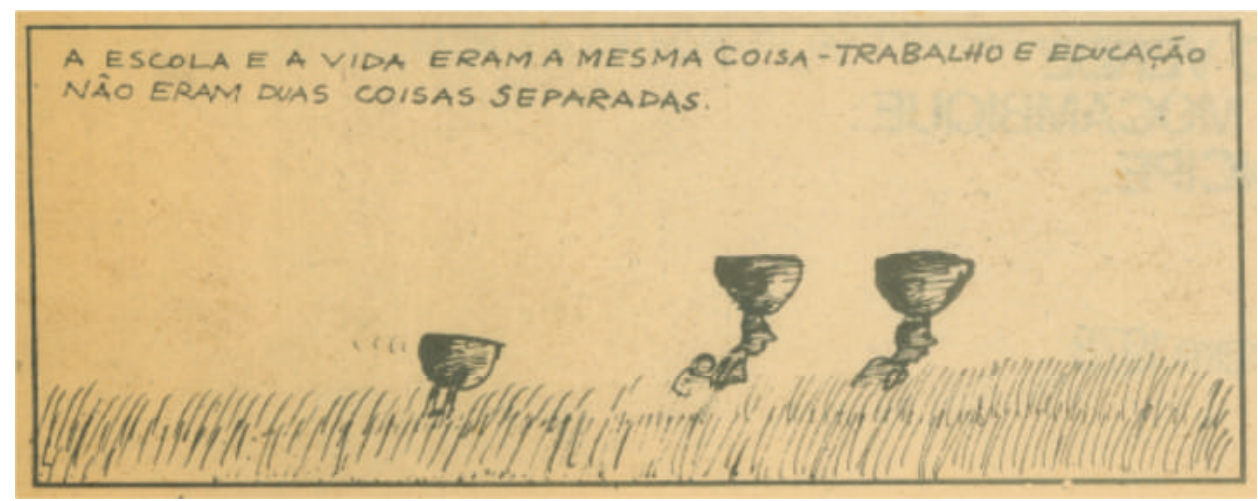

Fig. 20. Ligação palavra-imagem ironizante 
ANEXO 2

\section{FOSTERING CRITICAL THINKING CONTENT \& LANGUAGE}

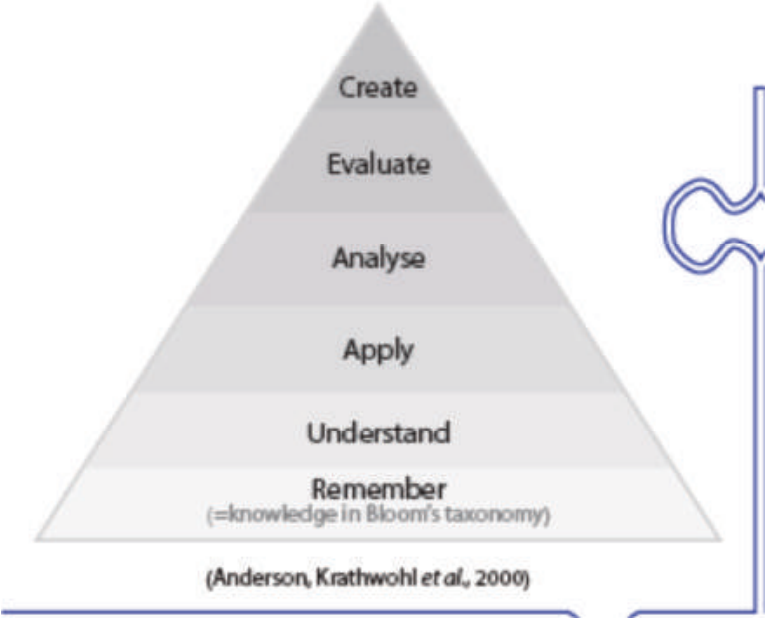

Fig. A. Como se nutre o pensamento crítico segundo Anderson/Krathwohl

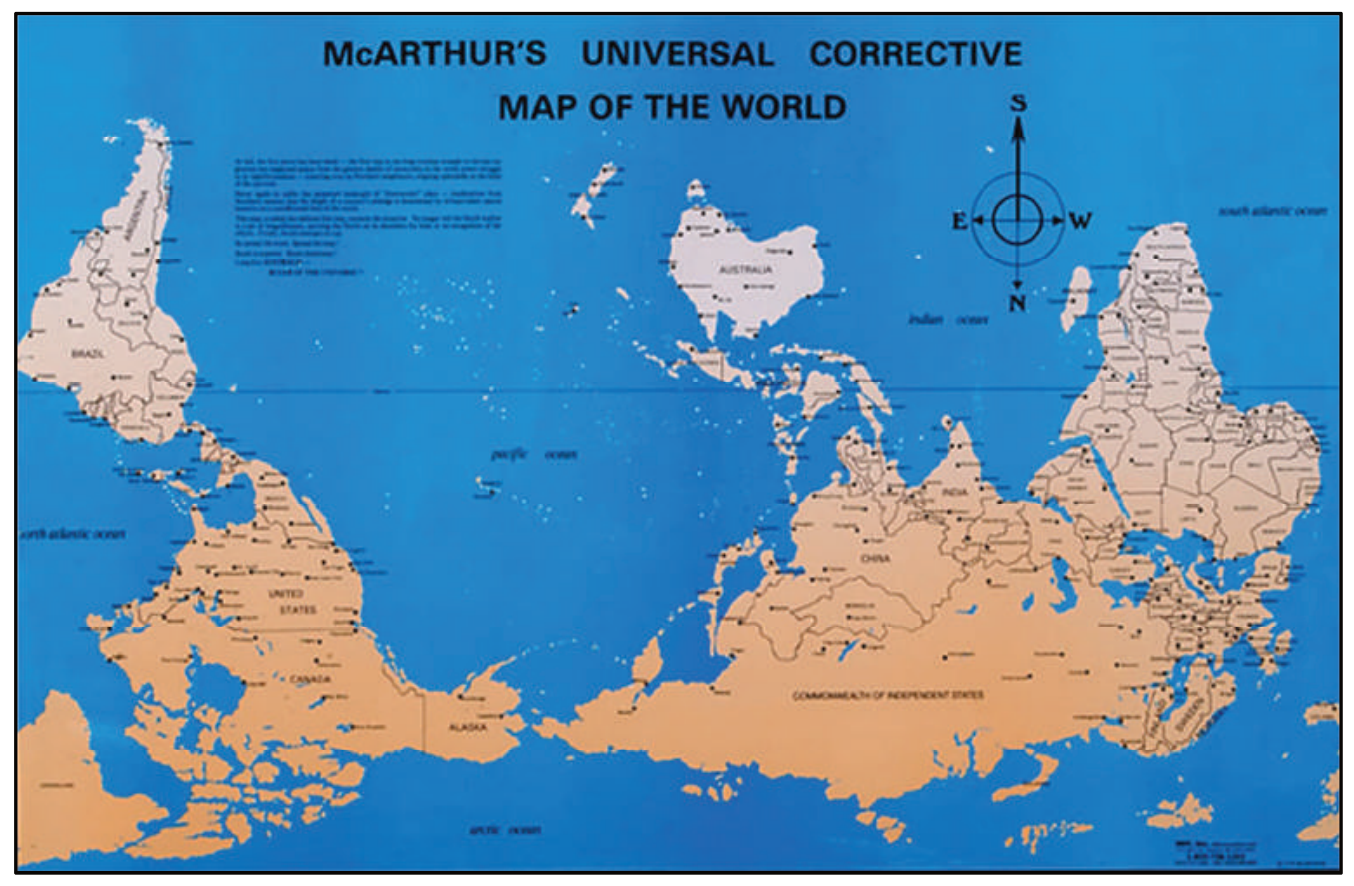

Fig. B. Como podemos ver o mundo segundo McArthur 